\title{
Dynamic regulation of extracellular ATP in Escherichia coli
}

\author{
Cora Lilia Alvarez ${ }^{1}$, Gerardo Corradi ${ }^{1,2}$, Natalia Lauri ${ }^{1}$, Irene Marginedas-Freixa ${ }^{3}$, María Florencia Leal \\ Denis $^{1,4}$, Nicolás Enrique ${ }^{5,6}$, Sabina María Mate ${ }^{7,8}$, Verónica Milesi ${ }^{5,6}$, Mariano Anibal Ostuni ${ }^{3}$, \\ Vanesa Herlax ${ }^{7,8}$ and Pablo Julio Schwarzbaum ${ }^{1,2}$
}

\begin{abstract}
${ }^{1}$ Universidad de Buenos Aires. Consejo Nacional de Investigaciones Científicas y Técnicas. Instituto de Química y Fisico-Química Biológicas (IQUIFIB) "Prof. Alejandro C. Paladini". Facultad de Farmacia y Bioquímica. Buenos Aires, Argentina; ${ }^{2}$ Universidad de Buenos Aires. Facultad de Farmacia y Bioquímica. Departamento de Química Biológica. Cátedra de Química Biológica Superior. Buenos Aires, Argentina; ${ }^{3}$ UMR-S1134, Integrated Biology of Red Blood Cells, Inserm, Université Paris Diderot, Sorbonne Paris Cité, Institut National de la Transfusion Sanguine, Laboratoire d'Excellence GR-Ex, F-75015. Paris, France; ${ }^{4}$ Universidad de Buenos Aires. Facultad de Farmacia y Bioquímica. Departamento de Química Analítica y Fisicoquímica. Cátedra de Química Analítica. Buenos Aires, Argentina; ${ }^{5}$ Universidad Nacional de la Plata. Consejo Nacional de Investigaciones Científicas y Técnicas. Instituto de Estudios Inmunológicos y Fisiopatológicos (IIFP). Facultad de Ciencias Exactas. La Plata, Argentina; ${ }^{6}$ Universidad Nacional de la Plata. Facultad de Ciencias Exactas. Departamento de Ciencias Biológicas. Cátedra de Fisiología. La Plata, Argentina; ${ }^{7}$ Universidad Nacional de La Plata. Consejo Nacional de Investigaciones Científicas y Técnicas. Instituto de Investigaciones Bioquímicas de La Plata (INIBIOLP) "Prof. Dr. Rodolfo R. Brenner". Facultad de Ciencias Médicas. La Plata, Argentina; and ${ }^{8}$ Universidad Nacional de La Plata. Facultad de Ciencias Médicas. La Plata, Argentina
\end{abstract}

Correspondence: Pablo Julio Schwarzbaum (pjs@qb.ffyb.uba.ar)

Received: 21 September 2016 Revised: 21 February 2017 Accepted: 24 February 2017

Accepted Manuscript online: 28 February 2017 Version of Record published: 4 April 2017
We studied the kinetics of extracellular ATP (ATPe) in Escherichia coli and their outer membrane vesicles (OMVs) stimulated with amphipatic peptides melittin (MEL) and mastoparan 7 (MST7). Real-time luminometry was used to measure ATPe kinetics, ATP release, and ATPase activity. The latter was also determined by following $\left[{ }^{32} \mathrm{P}\right] \mathrm{Pi}$ released from $\left[\gamma^{-}{ }^{32}\right.$ P]ATP. E. coli was studied alone, co-incubated with Caco-2 cells, or in rat jejunum segments. In $E$. coli, the addition of $\left[\gamma^{-32}\right.$ P]ATP led to the uptake and subsequent hydrolysis of ATPe. Exposure to peptides caused an acute 3-fold (MST7) and 7-fold (MEL) increase in [ATPe]. In OMVs, ATPase activity increased linearly with [ATPe] (0.1$1 \mu \mathrm{M})$. Exposure to MST7 and MEL enhanced ATP release by 3-7 fold, with similar kinetics to that of bacteria. In Caco-2 cells, the addition of ATP to the apical domain led to a steep [ATPe] increase to a maximum, with subsequent ATPase activity. The addition of bacterial suspensions led to a 6-7 fold increase in [ATPe], followed by an acute decrease. In perfused jejunum segments, exposure to $E$. coli increased luminal ATP 2 fold. ATPe regulation of $E$. coli depends on the balance between ATPase activity and ATP release. This balance can be altered by OMVs, which display their own capacity to regulate ATPe. E. coli can activate ATP release from Caco-2 cells and intestinal segments, a response which in vivo might lead to intestinal release of ATP from the gut lumen.

\section{Introduction}

In bacteria, as in most cell types and organisms, cytosolic adenosine triphosphate (ATPcyt) acts as an 'energy currency'; a regulated variable providing energy for metabolic reactions, serving as a substrate for nucleic acid synthesis, and regulating a variety of biological processes.

In Escherichia coli, the ATPcyt concentration ranges from 1 to $5 \mathrm{mM}$, depending on the environmental and physiological conditions [1-3]. The nucleotide is synthesized de novo or obtained from external purine compounds by salvage pathways [4].

ATPcyt of E. coli can be transported through the inner membrane (IM) to the periplasm, where it can be metabolized by various enzymes [5]. The resulting adenosine and adenine can be transported back through exchangers to the cytoplasm [4]. Alternatively, periplasmic ATP, as well as ADP, AMP, and other small hydrophilic solutes, can diffuse across the outer membrane (OM) through water-filled 
porins which are permeable to solutes smaller than 600-700 Da [6,7]. At neutral $\mathrm{pH}$, ATP is mainly an anionic species of $507 \mathrm{Da}$ capable of crossing the OM via one or more porins whose selectivity, on the basis of chemical structure, is poor [7-9].

Thus, there may be a dynamic exchange allowing ATP to be released from the periplasm or be taken up from the extracellular space. In agreement with these findings, extracellular ATP (ATPe) accumulated in nanoto low micromolar concentrations in E. coli cultures under different experimental conditions [10-12].

E. coli possesses periplasmic nucleotidases and phosphatases capable of hydrolyzing ATP [5,13]. An enzyme encoded by the ushA gene displayed $5^{\prime}$-nucleotidase activity in E. coli [5,14], facilitating the hydrolysis of ATP, ADP, AMP, and other 5'ribo and $5^{\prime}$ deoxyribonucleotides [15]. In addition, there are at least two periplasmic phosphatases capable of dephosphorylating ATP: AphA, an acid phosphatase exhibiting hydrolytic activity in an acid milieu [16] and PhoA, an alkaline phosphatase, exhibiting activity at pH 7-9. PhoA can be either transcriptionally up-regulated in the absence of $\mathrm{Pi}[17]$ or kinetically inhibited by high $\mathrm{Pi}[18,19]$.

Bacterial release of ATP may occur by lytic and non-lytic mechanisms. In E. coli, hypotonic treatment, carbon starvation, as well as exposure to glucose or carbon monoxide, promote the non-lytic release of ATP and other solutes $[12,20,21]$. Repression of 5 'nucleotidases, on the other hand, leads to basal excretion of purine nucleotides, although ATP export was not tested [5].

Amphipatic peptides can enhance the permeability to small solutes in a variety of cells [9,22-30], either by creating disordered regions of the lipid bilayer and/or by forming pores [31-35]. Among these are small amphipatic peptides belonging to the mastoparan and melittin families, which display a broad spectrum of lytic activities in a variety of cells [36,37], inducing ATP release in erythrocytes [38,39] and adrenal chromaffin cells [40]. Mastoparans exhibit antimicrobial activity against both Gram-positive and -negative bacteria, though in E. coli the OM had to be previously disrupted in order for mastoparan to be effective [22,23].

Melittin, on the other hand, was rapidly taken up by E. coli, inducing morphological changes usually followed by leakage of the cytoplasm [9,37].

In principle, [ATPe] of E. coli may increase via cytoplasmic/periplasmic ATP release induced by physiological and pharmacological stimuli, and/or decrease via ATPe hydrolysis due to periplasmic nucleotidases.

Thus, in the present study we evaluated the relative contribution of ATPe hydrolysis and ATP release to the dynamic regulation of ATPe of E. coli. Melittin and mastoparan 7 (an active mastoparan analog; [41]) were used as ATP release inducers.

E. coli are able to form and release outer membrane vesicles (OMVs) both in vivo and in vitro [42-44]. Since the lumen of these vesicles may contain ATP as well as nucleotidases of periplasmic origin [45,46], our analysis of the dynamic ATPe regulation of $E$. coli took the contribution of OMVs into account.

Finally, we analyzed ATPe regulation in conditions closer to the in vivo situation, where E. coli lives as a commensal of the gut lumen, in close contact with intestinal epithelial cells. Accordingly, we studied the effect of $E$. coli on ATPe regulation of the human intestinal Caco-2 cell line and rat intestinal segments.

\section{Materials and methods Chemicals}

All reagents were of analytical grade. Mastoparan 7 (MST7), mastoparan 17 (MST17), melittin (MEL), and firefly luciferase (EC1.13.12.7) were purchased from Sigma-Aldrich (St. Louis, MO, U.S.A.). D-luciferin was obtained from Molecular Probes Inc. (Eugene, OR, U.S.A.). $\left[\gamma^{32} \mathrm{P}\right] \mathrm{ATP}(10 \mathrm{Ci} / \mathrm{mmol})$ was purchased from Perkin Elmer Life Sciences (Santa Clara, California, U.S.A.). Phosphatidylglycerol, cardiolipin, and phosphatidylethanolamine were purchased from Avanti Polar Lipids (AL, U.S.A.).

\section{Bacterial strains and culture conditions}

E. coli $\mathrm{DH} 5 \alpha$ was used in all experiments using bacteria and OMVs, the only exception being the experiments run to assess $\beta$-galactosidase activity (see M\&M), where E. coli BL21 (DE3) was used. Both strains showed similar responses to MST7 and MEL (Supplementary Figure S1).

E. coli were cultured overnight in Luria-Bertani (LB) broth at $37^{\circ} \mathrm{C}$, with shaking at $220 \mathrm{rpm}$. Overnight cultures were diluted 1:100 in fresh $\mathrm{LB}$ broth and cultured at $37^{\circ} \mathrm{C}$ with shaking. Growth was monitored by optical density at $600 \mathrm{~nm}\left(\mathrm{OD}_{600}\right)$. Bacteria were harvested when an $\mathrm{OD}_{600}$ of $0.6-0.9$ was attained. Bacterial cultures were then centrifuged $2500 \times g$ for $5 \mathrm{~min}$, the supernatant was removed, and the pellet resuspended at $2 \times 10^{9}$ bacteria/ml in $\mathrm{M} 9$ medium containing: $\mathrm{Na}_{2} \mathrm{HPO}_{4} 42.3 \mathrm{mM}, \mathrm{KH}_{2} \mathrm{PO}_{4} 22.1 \mathrm{mM}, \mathrm{NH}_{4} \mathrm{Cl} 18.7 \mathrm{mM}, \mathrm{MgSO}_{4}$ 
$7 \mu \mathrm{M}, \mathrm{NaCl} 108 \mathrm{mM}$, and $\mathrm{CaCl}_{2} 0.1 \mathrm{mM} ; \mathrm{pH}$ 7. Centrifugation and washing of the pellet was repeated three times.

For experiments run in the absence of phosphate, overnight cultured bacteria were harvested, washed, and resuspended in a similar way, except that (Hepes $10 \mathrm{mM}, \mathrm{KCl} 1 \mathrm{mM}, \mathrm{NaCl} 140 \mathrm{mM} ; \mathrm{pH}=7$ ) was used.

In most cases, bacterial suspensions were preincubated in M9 or Hepes media for 60 min before use. In a few experiments (see the 'Rat intestinal perfusates' section below), intact jejunum segments were exposed to supernatants collected from E. coli suspensions. In this case, E. coli were cultured in the LB medium as above, centrifuged, and the resulting supernatant was collected.

\section{Isolation of OMVs}

Bacteria were cultured as above and OMVs were isolated from bacterial culture supernatants as described previously [47]. Bacteria were then pelleted $\left(2500 \times \mathbf{g}\right.$ for $10 \mathrm{~min}$ at $\left.4^{\circ} \mathrm{C}\right)$, and culture supernatants filtered using $0.22 \mu \mathrm{m}$ pore size filters (Millipore Corporation, Billerica, MA, U.S.A.), followed by centrifugation at $166000 \times g$ for $2 \mathrm{~h}$ at $4^{\circ} \mathrm{C}$. The resulting pellet containing the OMVs was diluted in the M9 medium, and held at $4^{\circ} \mathrm{C}$ for up to $48 \mathrm{~h}$ before use. An aliquot was withdrawn to determine protein content using the Bradford assay. Total lipids of OMVs were extracted using a standard procedure [48] and subjected to analysis by high-performance TLC, using the following solvent system: chloroform/methanol/2-propanol/0.25\% KCl/ethylacetate $(30+9+25+6+18)$. Lipid spots were detected by spraying with sulfuric acid/ethanol $(5: 100, \mathrm{v} / \mathrm{v})$ and charring at $120^{\circ} \mathrm{C}$. Phosphatidylglycerol (PG), cardiolipin (CL), phosphatidylethanolamine (PE), and lipopolysaccharide (LPS) were used as standards. Preliminary experiments showed that ATPase activity (assayed by the two methods described below, see 'Hydrolysis of ATPe' section in M\&M) of OMVs were similar for suspensions stored for 24 or $48 \mathrm{~h}$ at $4^{\circ} \mathrm{C}$ before use (data not shown).

Aliquots of OMVs suspensions $(10 \mu \mathrm{l})$ were spotted on LB agar plates for overnight culture at $37^{\circ} \mathrm{C}$. No bacterial colonies were observed.

\section{Electron microscopy}

OMVs were observed by electron microscopy. Vesicles were fixed with $1 \%(\mathrm{v} / \mathrm{v})$ glutaraldehyde for $45 \mathrm{~min}$ at room temperature, centrifuged $\left(166000 \times \mathrm{g}\right.$ for $2.5 \mathrm{~h}$ at $\left.4^{\circ} \mathrm{C}\right)$, and resuspended in $0.1 \mathrm{M}$ ammonium acetate buffer $(\mathrm{pH}=7)$. A drop of fixed vesicles was applied to a 400 mesh copper grid covered with a carbon film and the samples were stained with $2 \%(\mathrm{w} / \mathrm{v})$ phosphotungstic acid $(\mathrm{pH} 5.2$ with $\mathrm{KOH})$. Electron micrographs were taken at $50000 \times$ magnification.

\section{Culture of Caco-2 cells}

Caco-2 cells (passages 5-10, ATCC, Molsheim, France) were seeded on Snapwell tissue culture-treated polycarbonate membrane filters $(6.5 \mathrm{~mm}$ diameter and $0.4 \mu \mathrm{m}$ pore size; Corning, New York, U.S.A.). Cells were grown for 15-30 days on Dulbecco's modified Eagle's medium containing $4.5 \mathrm{~g} / \mathrm{l}$ glucose supplemented with $10 \% \mathrm{v} / \mathrm{v}$ fetal bovine serum, $2 \mathrm{mM}$ l-glutamine, and antibiotics in a humidified atmosphere of $5 \% \mathrm{CO}_{2}$ at $37^{\circ} \mathrm{C}$. Experiments were performed on confluent cells that had developed a transepithelial electrical resistance greater than $250 \mathrm{w} / \mathrm{cm}^{2}$. Under these conditions, cells formed a polarized epithelial cell monolayer with distinguished apical and basolateral domains. Membrane permeability was tested by adding dextran-FITC (MW $=59000-77000 \mathrm{Da}$, Sigma,) to the upper chamber (apical side) and measuring fluorescence (exc/emi 490/520 nm) on the lower chamber (basolateral side).

\section{Rat intestinal perfusates}

Adult Wistar rats of either sex of 250-350 g body weight were anesthetized. Jejunum segments (approximately $10 \mathrm{~cm}$ long) were excised from animals and immediately placed in cold Ringer buffer containing (in $\mathrm{mM}$ ): $\mathrm{NaCl} 130, \mathrm{KCl} 4.7, \mathrm{KH}_{2} \mathrm{PO}_{4} 1.2, \mathrm{CaCl}_{2} 2.5, \mathrm{MgSO}_{4} 1.2, \mathrm{NaHCO}_{3} 24$, glucose 6, oxygenated with a mixture of $95 \% \mathrm{O}_{2}$ and $5 \% \mathrm{CO}_{2}, \mathrm{pH}$ 7.4. The intestinal segment was flushed of luminal contents and placed in an organ bath containing $10 \mathrm{ml}$ of Ringer solution kept at room temperature. The proximal and distal ends of the jejunum were cannulated to allow slow infusion of Ringer solution at $37^{\circ} \mathrm{C}$ with a flow rate of $1 \mathrm{ml} / \mathrm{min}$ using a peristaltic pump (Model E50, Elmeco Laboratory Instruments).

During the first 30 min the tissue was infused with Ringer solution and then replaced by a bacterial suspension, containing $5 \times 10^{8}$ bacteria/ml in the same saline solution. Samples were collected at the distal end every 10 min during $60 \mathrm{~min}$ and the luminal $\mathrm{ATP}\left(\mathrm{ATP}_{\mathrm{L}}\right)$ was measured by off-line luminometry immediately after 
sample collection. In some experiments, before replacing the Ringer solution with the bacterial suspension, supernatants collected from E. coli suspensions were perfused.

\section{Treatments}

The ATPe kinetics of E. coli was assessed when bacteria were exposed to mastoparan 7 (MST7) or melittin (MEL). $\alpha, \beta$-methyleneadenosine 5 -triphosphate lithium salt (AMP-CPP, a non-hydrolyzable ATP analog) was used as an inhibitor of ATPase activity via one or more enzymes.

ATPe kinetics of Caco-2 cells was assessed following exposure to bacteria (E. coli) or to an adrenergic cocktail denoted as $3 \mathrm{~V}$, which contained $10 \mathrm{mM}$ isoproterenol (a $\beta$-adrenergic agonist), $30 \mathrm{mM}$ forskolin (an adenylate kinase activator), and $100 \mathrm{mM}$ papaverine (a phosphodiesterase inhibitor). $3 \mathrm{~V}$ was used to induce a fast increase in cytosolic cAMP. Experiments with Caco-2 cells exposed to either bacteria or 3V were carried out in the absence or presence of carbenoxolone, an inhibitor of ATP release.

Intact jejunum segments were continuously infused with either $E$. coli suspensions or supernatants collected from E. coli suspensions, and the perfusates were used for ATP determination by off-line luminometry.

\section{Extracellular ATP}

ATPe was measured by real-time luminometry with bacteria, OMVs, and Caco-2 cells using firefly luciferase, which catalyzes the oxidation of luciferin in the presence of ATP to produce light. In experiments using rat intestinal segments, the presence of ATP in the intestinal lumen was assessed by off-line luminometry. A custom-built luminometer of high sensitivity was used $[49,50]$.

\section{On-line luminometry}

\section{E. coli and OMVs}

Real-time luminometry was carried out with bacteria or OMVs laid on coverslips that were mounted in the assay chamber of the luminometer. Measurements were performed in M9 medium containing a luciferinluciferase mixture at $20^{\circ} \mathrm{C} .2 \times 10^{7}$ bacteria/40 or $10 \mu$ l OMVs $(0.8-1.4 \mu \mathrm{g}$ protein $) / 100 \mu \mathrm{l}$ were used.

The time course of light emission was transformed into ATPe concentration versus time by means of a calibration curve. Increasing concentrations of ATP from 4 to $974 \mathrm{nM}$ were sequentially added to the assay medium from a stock solution of ATP dissolved in the M9 medium. For the results shown in Figure 4C, the instantaneous rate of $[\mathrm{ATPe}]$ change (denoted as $\mathrm{P}_{\mathrm{ATP}}$ ) was calculated by taking the first derivative of the experimentally observed ATPe kinetics of Figure 4A,B.

\section{Caco-2 cells}

Caco- 2 cells were grown and polarized on permeable supports as described above. Real-time luminometry was carried out by placing these supports, containing approximately $5 \times 10^{5}$ cells, in the assay chamber of the luminometer. The configuration of the set-up is illustrated in Supplementary Figure S2. Measurements were run at $20^{\circ} \mathrm{C}$. The basolateral side was loaded with $40 \mu \mathrm{l}$ of DPBS medium (Gibco ${ }^{\mathrm{TM}}$ ), while the apical side was loaded with $40 \mu \mathrm{l}$ of DPBS medium containing a luciferin-luciferase mixture. Using this configuration, the light-emitting luciferase reaction occurs in the apical domain.

The time course of light emission was transformed into ATPe concentration versus time by means of a calibration curve. Increasing concentrations of ATP $(24-875 \mathrm{nM})$ were sequentially added to the assay medium from a stock solution of ATP dissolved in DPBS medium. Results were expressed as [ATPe] at every time point of a kinetic curve.

Increases in [ATPe] were evaluated as the difference between [ATPe] at $1 \mathrm{~min}$ post-stimulus and the basal [ATPe], and are indicated as $\triangle \mathrm{ATP}_{1}$.

\section{Off-line luminometry of rat intestinal perfusates}

Aliquots $\left(45 \mu \mathrm{l}\right.$ ) of perfusates, were taken every $10 \mathrm{~min}$, containing 0 (control) or $5 \times 10^{8}$ bacteria $/ \mathrm{ml}$ and used to measure $\mathrm{ATP}_{\mathrm{L}}$. A standard ATP curve was obtained for each sample by adding $1 \mu$ l of increasing concentrations of ATP from 1 to $20 \mu \mathrm{M}$. For each experiment, concentrations of $\operatorname{ATP}_{\mathrm{L}}$ were normalized to the control conditions in the absence of bacteria. 


\section{Intracellular ATP}

The intracellular ATP content of E. coli was estimated using real-time measurements. Briefly, $10 \mu \mathrm{l}$ of a bacterial suspension $\left(2 \times 10^{8}\right.$ bacteria) was placed on a coverslip. Samples were desiccated at room temperature to induce bacteriolysis [32]. The desiccated residue was dissolved in $40 \mu \mathrm{l}$ of M9 medium containing a luciferinluciferase mixture, and the total content of ATP was measured by luminometry as described in 'On-line luminometry section in M\&M'.

\section{Hydrolysis of ATPe}

The rate of ATPe hydrolysis was tested in bacteria, OMVs, and polarized Caco-2 cells. It was determined by following the accumulation of $\left[{ }^{32} \mathrm{P}\right] \mathrm{Pi}$ release from exogenous $\left[\gamma^{32} \mathrm{P}\right] \mathrm{ATP}$, and by real-time luminometry.

\section{$\left[\gamma-{ }^{32}\right.$ P]ATP technique $[38,51]$}

This technique was used for bacteria, OMVs, and Caco- 2 cells. The reaction was started by adding $\left[\gamma_{-}{ }^{32} \mathrm{P}\right] \mathrm{ATP}$ $(0.27 \mathrm{Ci} / \mathrm{mmol}$; from 100 to $1000 \mathrm{nM})$ to bacterial or OMVs suspensions at $20^{\circ} \mathrm{C}$. At different times, $100 \mu \mathrm{l}$ aliquots of the suspension were withdrawn in duplicate and were poured into $750 \mu \mathrm{l}$ of a stop solution containing $4.05 \mathrm{mM}\left(\mathrm{NH}_{4}\right)_{6} \mathrm{Mo}_{7} \mathrm{O}_{24}$ and $0.83 \mathrm{mM} \mathrm{HClO}$ (molybdate-perchloric solution). The ammonium molybdate solution formed a complex with the released phosphate, which was then extracted with $0.6 \mathrm{ml}$ of isobutyl alcohol. Phases were separated by centrifugation at $1000 \times \mathrm{g}$ for $5 \mathrm{~min}$, aliquots of $200 \mu \mathrm{l}$ of the organic phase containing $\left[{ }^{32} \mathrm{P}\right] \mathrm{Pi}$ were transferred to vials with $2 \mathrm{ml}$ of $0.5 \mathrm{M} \mathrm{NaOH}$ and radioactivity was measured using the Cerenkov effect. Any hydrolysis of $\left[\gamma^{32} \mathrm{P}\right] \mathrm{ATP}$ into ADP $+\left[{ }^{32} \mathrm{P}\right] \mathrm{Pi}$ in the bacterial or OMVs suspensions can be defined as ATPase activity; the time course of $\left[{ }^{32} \mathrm{P}\right] \mathrm{Pi}$ accumulation yields a measure of the rate at which one or more nucleotidases or phosphatases of the samples hydrolyze ATPe.

To calculate ATPase activity, time-dependent levels of Pi were fitted to

$$
Y=Y 0+A\left(1-\exp ^{-k \cdot t}\right)
$$

where $Y$ and $Y 0$ are the values of $\left[{ }^{32} \mathrm{Pi}\right]$ at each time $(t)$ and at $t=0$, respectively; $A$ represents the maximal value for the increase in $Y$ with time and $k$ is a rate coefficient. The parameters of best fit resulting from the regression were used to calculate the initial rate of ATPase activity (vi) as $k \times A$ (i.e. the first derivative of Eq. (1) evaluated at $t=0)$. The $\left[{ }^{32} \mathrm{Pi}\right] \mathrm{Pi}$ moles produced from $\left[\gamma^{-}{ }^{32} \mathrm{P}\right]$ ATP were calculated using the ATP specific activity.

In a few experiments, instead of using submicromolar ATP concentrations, ATPase activity was detected at $500 \mu \mathrm{M}$ ATP to provide an estimate of apparent maximal ATPase activity (Vi).

ATPase activity was expressed as: $\mathrm{pmol} /\left(10^{10}\right.$ bacteria $\left.\mathrm{min}\right)$ in $E$. coli suspensions, $\mathrm{pmol} /(\mu \mathrm{g}$ prot $)$ in $\mathrm{OMVs}$, or $\mathrm{nM} / \mathrm{min}$ in Caco-2 cells.

\section{Uptake and hydrolysis of ATPe in E. coli}

E. coli has cytosolic and periplasmic compartments. Unless otherwise stated, by uptake of ATPe we mean that ATPe should enter the periplasm, irrespective of its final location or metabolism inside the bacterium.

Aliquots $(100 \mu \mathrm{l})$ of $E$. coli suspensions were incubated with $1 \mu \mathrm{M}\left[\gamma^{-32} \mathrm{P}\right]$ ATP for 2 or $30 \mathrm{~min}$, after which they were diluted in $1.4 \mathrm{ml}$ of cold M9 medium, and centrifuged for $5 \mathrm{~min}$ at $2400 \times \mathrm{g}$. The resulting pellets were treated in two different ways: 1 ) they were transferred to vials containing $2 \mathrm{ml}$ of $0.5 \mathrm{M} \mathrm{NaOH}$. This provided a measure of total radioactivity being taken up by bacteria, irrespective of ATP hydrolysis, 2) pellets were first resuspended in the M9 medium, centrifuged for $1 \mathrm{~min}$ at $2400 \times \mathrm{g}$, and the resulting pellet dissolved in $600 \mu \mathrm{l}$ of a molybdate-percholoric solution, and treated as described for ATPase activity measurements. That is, the solution was extracted with $0.48 \mathrm{ml}$ of isobutyl alcohol and molybdate-percholoric phases were separated by centrifugation. Aliquots of both phases were transferred to vials with $2 \mathrm{ml}$ of $0.5 \mathrm{M} \mathrm{NaOH}$. The organic phase was used to determine the amount of $\left[{ }^{32} \mathrm{Pi}\right] \mathrm{Pi}$ produced from $\left[\gamma^{32} \mathrm{P}\right] \mathrm{ATP}$, while the molybdateperchloric phase was used to determine the amount of $\left[\gamma^{32} \mathrm{P}\right]$ ATP remaining after hydrolysis. Radioactivity was measured using the Cerenkov effect.

\section{ATPe hydrolysis by real-time luminometry}

This method was used for studies with OMVs and Caco- 2 cells. 


\section{OMVs}

Coverslips with $10 \mu \mathrm{l}$ of OMV suspensions were mounted in the measuring chamber of the luminometer and exposed to the luciferase reaction mixture. Light emission was measured for $10 \mathrm{~min}$, ATP was then added to the chamber at final concentrations of 200,600 , and $1000 \mathrm{nM}$ (in separate experiments) and measurements were carried out for another $30 \mathrm{~min}$.

Light output was transformed into ATPe concentration vs. time by means of a calibration curve and the slope of disappearance of ATPe (vi) was estimated from ATPe kinetics and multiplied by -1 . ATPase activity was expressed as $\mathrm{nM} /(\mu \mathrm{g}$ prot $\mathrm{min})$.

\section{Caco-2 cells}

Measurements were performed on the apical side of polarized cells held on permeable supports as described in the 'Culture of Caco-2 cells' section.

Basal light emission was measured for $5 \mathrm{~min}$, ATP $(0.2-7 \mu \mathrm{M})$ or aliquots of $E$. coli suspensions were then added to the upper chamber at a given concentration and measurements were carried out for another 15-20 min. Light output was transformed into ATPe concentration vs. time by means of a calibration curve ('On-line luminometry' section) and the slope of disappearance of ATPe (vi) was estimated from the maximum value of ATPe kinetics until the end of the experiment, and multiplied by -1 . ATPase activity was expressed as $\mathrm{nM} / \mathrm{min}$.

\section{Hydrolysis of $\boldsymbol{p}$-nitrophenyl phosphate}

$p$-nitrophenyl phosphate ( $\mathrm{pNPP}$ ) was used as a substrate to estimate periplasmic phosphatase activity of $E$. coli suspensions $\left(2 \times 10^{9}\right.$ bacteria/ml). pNPP phosphatase activity was measured using a spectrophotometric assay, based on the ability of phosphatases to catalyze the hydrolysis of pNPP to $p$-nitrophenol, a chromogenic product with absorbance at $420 \mathrm{~nm}$ [52]. Initial velocities were calculated as in the 'Hydrolysis of ATPe' section (Eq. 1).

\section{Viability}

Viability was tested by the capacity of $E$. coli to form colonies (culturability) and their IM integrity ( $\beta$-galactosidase assay).

\section{Culturability}

Bacteria were grown overnight, harvested, and resuspended in M9 as explained in the 'Bacterial strains and culture conditions' section. Suspensions of bacteria $\left(2 \times 10^{7}\right.$ bacteria/40 $\left.\mu \mathrm{l}\right)$ were held in the absence of treatments (controls) or were exposed to MST7, MST17, or MEL for 1 or $20 \mathrm{~min}$ at $20^{\circ} \mathrm{C}$. Afterwards, suspensions were diluted $1 / 25000$ and $10 \mu \mathrm{l}$ aliquots were spotted on LB agar plates for overnight culture at $37^{\circ} \mathrm{C}$. Colony formed units (CFU) were counted manually and expressed relative to control values.

\section{$\beta$-galactosidase assay}

This method was used to assess the IM integrity of E. coli. E. coli BL21 (DE3) were electroporated with a pGEM3ZF plasmid containing a gene encoding $\beta$-galactosidase. Transformed bacterial cultures were grown $\left(37^{\circ} \mathrm{C}, 200 \mathrm{rpm}\right)$ and $\beta$-galactosidase expression was induced by the addition of $1.0 \mathrm{mM}$ IPTG to the culture medium. After induction for $3 \mathrm{~h}$, bacterial suspensions were centrifuged at $2500 \times \mathrm{g}$ for $5 \mathrm{~min}$, the supernatant was removed, and the pellet was resuspended at $2 \times 10^{9}$ bacteria $/ \mathrm{ml}$ in the M9 medium. Centrifugation and washing of the pellet was repeated three times.

Transformed bacteria were exposed to the chromogenic lactose analog ONPG (o-nitrophenyl $\beta$-D-galactopyranoside) in the absence of any treatment (non-treated), or in the presence of MST7, MST17, or MEL.

Agents that compromise IM integrity would permit ONPG to diffuse into the bacterial cytoplasm, where it can be hydrolyzed to ONP (o-nitrophenol) by $\beta$-galactosidase activity. Accordingly, the concentration of ONP was followed by measuring the absorbance at $415 \mathrm{~nm}$ with $1 \mathrm{~min}$ intervals for $60 \mathrm{~min}$ at $20^{\circ} \mathrm{C}$, using a Bio-Rad 550 plate reader. Data were normalized by subtracting absorbance at $t=0$. The kinetics of ONP production was determined for each treatment. 


\section{Data analysis}

Statistical significance was determined using one-way Analysis of Variance followed by a Tukey Multiple Comparison Test. A $P$ value $<0.05$ was considered significant. Numbers of determinations $(n)$ from independent preparations $(N)$ are indicated. In the experiments using Caco-2 cells, each filter containing polarized monolayers was considered an independent preparation. In experiments using rat intestinal segments, only one segment was excised from each rat. Each segment was considered an independent preparation.

\section{Results}

Experiments were performed using suspensions of E. coli, OMVs, Caco-2 cells, or intestinal rat segments. In these systems, regulation of [ATPe] may depend on the dynamic balance between the rates of ATP release and ATPe hydrolysis. The relative importance of both processes can be assessed by measuring the kinetics of ATPe accumulation (denoted as ATPe kinetics) and ATPase activity.

\section{E. coli}

\section{ATPase activity}

Bacterial suspensions were exposed to $\left[\gamma^{32} \mathrm{P}\right] \mathrm{ATP}$ at various ATP concentrations $(100-1000 \mathrm{nM})$, and the time course of $\left[{ }^{32} \mathrm{P}\right] \mathrm{Pi}$ accumulation released from $\left[\gamma^{-32} \mathrm{P}\right] \mathrm{ATP}$ was determined (Figure $1 \mathrm{~A}$ ). The experimental

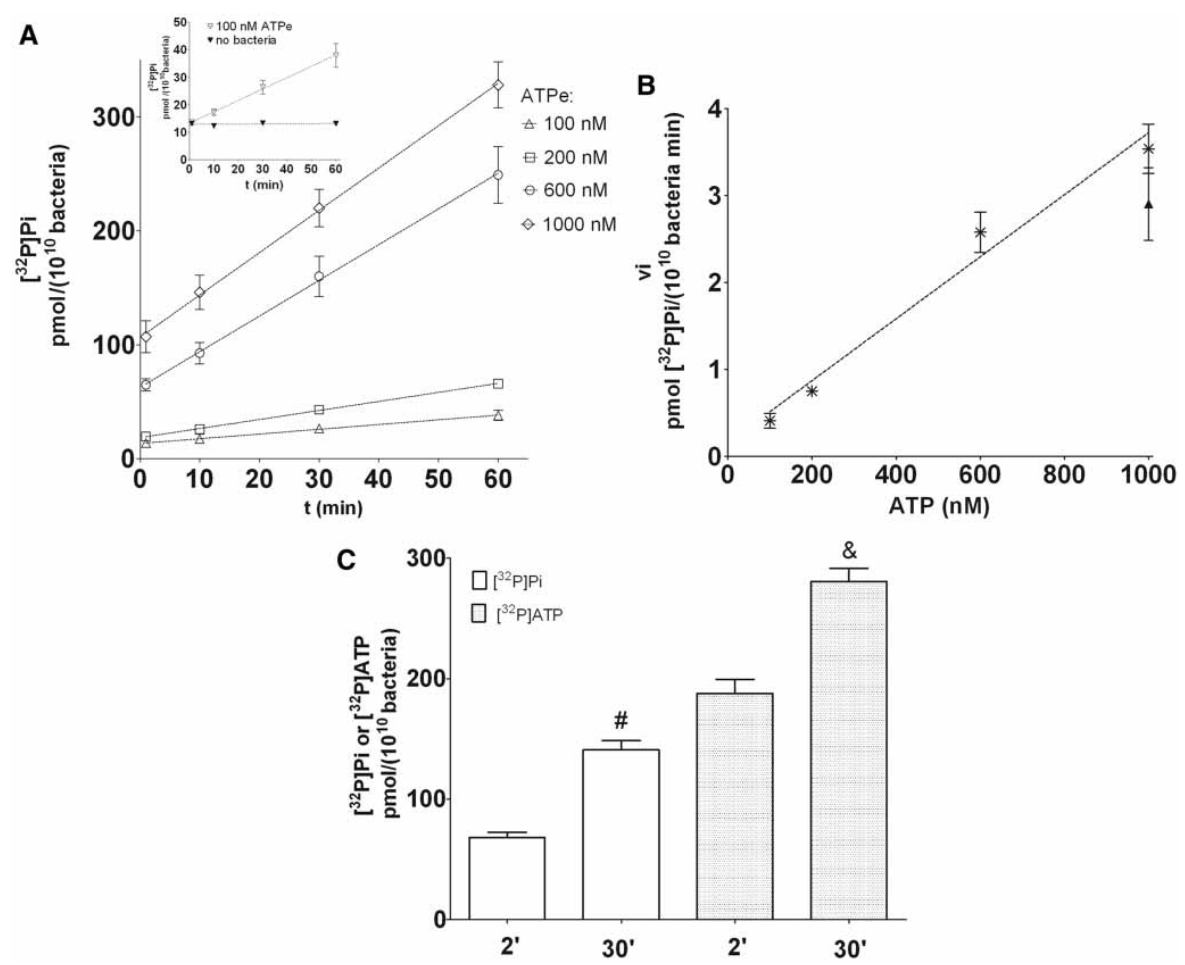

Figure 1. ATPase activity in E. coli.

(A) Time course of $\left[{ }^{32} \mathrm{P}\right] \mathrm{Pi}$ accumulation released from $\left[\gamma^{-32} \mathrm{P}\right] \mathrm{ATP}(100-1000 \mathrm{nM})$ using E. coli suspended in the M9 medium. The dotted lines represent fittings of linear functions to experimental data for each [ATP] used. Results are expressed as pmol $\left[{ }^{32} \mathrm{P}\right] \mathrm{Pi} /\left(10^{10}\right.$ bacteria), and are means $\pm \operatorname{SEM}(N=6-10, n=12-20)$. The inset shows the time course of $\left.{ }^{32} \mathrm{P}\right] \mathrm{Pi}$ accumulation at $100 \mathrm{nM}$, in media with or without bacteria. (B) ATPase activity (vi) as a function of [ATP]. Each symbol represents ATPase activity calculated as the rate of $\mathrm{Pi}$ kinetics using data from $\mathbf{A}$. The dotted line represents the fit of a linear function to experimental data. Results are expressed as pmol $\left[{ }^{32} \mathrm{P}\right] \mathrm{Pi} /\left(10^{10}\right.$ bacteria $\left.\mathrm{min}\right)$, and are means $\pm \mathrm{SEM}$. The triangle symbol represents ATPase activity derived from ATP uptake experiments of $\mathbf{C}$ below. (C) Uptake of ATPe. E. coli suspensions were exposed to $1 \mu \mathrm{M}\left[\gamma_{-}{ }^{32} \mathrm{P}\right] \mathrm{ATP}$ for 2 and $30 \mathrm{~min}$. Results show intracellular concentrations of $\left[\gamma^{-32} \mathrm{P}\right] A T P$ or its hydrolysis product $\left.{ }^{32} \mathrm{P}\right] \mathrm{Pi}$; they are means $\pm \operatorname{SEM}(N=3, n=12)$ expressed as pmol $/\left(10^{10}\right.$ bacteria). ( ${ }^{\&}$ and ${ }^{\#}$ denote $P<0.05$ for $\left[\gamma^{-}{ }^{32} \mathrm{P}\right] \mathrm{ATP}$ and $\left[{ }^{32} \mathrm{P}\right] \mathrm{Pi}$, respectively). $n, N$ denote number of replicates $(n)$ and independent experiments $(N)$. 
design for assessing ATPase activity of the periplasm relies on the fact that ATPe is permeable to the OM, but not the IM $[4,5]$. The initial rate values of $\left[{ }^{32} \mathrm{P}\right] \mathrm{Pi}$ production were used to calculate ATPase activity for each ATPe concentration. ATPase activity followed a linear function with ATPe concentrations (Figure 1B), with the slope of the curve $\left(K_{\mathrm{ATP}}\right)$ amounting to $0.04 \mathrm{~min}^{-1}$ per $10^{10}$ bacteria. Spontaneous ATPe hydrolysis in the absence of bacteria was negligible (inset Figure 1A).

\section{Phosphatase activity}

At neutral $\mathrm{pH}$, E. coli may exhibit periplasmic ATPase activity by $5^{\prime}$-nucleotidase and alkaline phosphatase. If the latter were active under experimental conditions, then it should be kinetically inhibited by Pi, and activated at alkaline $\mathrm{pH}[8,17,53]$.

Accordingly, we assessed and compared ATPase activity for bacteria suspended in the M9 medium, which contains phosphate, with that in Hepes medium, which lacked phosphate. Bacterial suspensions were grown in LB broth (see 'Bacterial strains and culture conditions' in the M\&M section). They were then collected and resuspended in either M9 or Hepes media. Experiments were run at low [ATPe] (600 nM, Figure 2A) or high [ATPe] $(500 \mu \mathrm{M}$, Figure 2B), the latter a measure of apparent maximal ATPase activity (Vi). ATPase activities in the Hepes medium were 3.3 -fold $(600 \mathrm{nM} \mathrm{ATPe})$ and 16 -fold $(500 \mu \mathrm{M}$ ATPe) higher than those in the M9 medium (Figure $2 \mathrm{C}, \mathrm{D})$. Vi was $3.27 \pm 1.70 \mathrm{nmol} /\left(10^{10}\right.$ bacteria $\mathrm{min}$ ) in the Hepes medium and $0.24 \pm$ $0.07 \mathrm{nmol} /\left(10^{10}\right.$ bacteria min) in the M9 medium (Figure $\left.2 \mathrm{D}\right)$.

As a further test for the inhibitory effect of Pi on ATPase activity of alkaline phosphatase, we incubated bacteria in Hepes medium containing the same Pi concentration as in the M9 medium. Results showed that, under these conditions, ${ }^{32} \mathrm{Pi}$ production at $600 \mathrm{nM}$ ATP was similar to that found in the M9 medium (Figure 2E). Moreover, while in the M9 medium the ATPase activity, due to $5^{\prime}$-nucleotidase activity, at $\mathrm{pH}=9$ was roughly similar to that found at $\mathrm{pH}=7$, in the Hepes medium ATPase activity was almost 2-fold higher at $\mathrm{pH}=9$ than at $\mathrm{pH}=7$.

Finally, we tested the capacity of bacterial suspensions to hydrolyze pNPP, a chromogenic product that acts as a substrate for phosphatases, but not for 5'-nucleotidase. As shown in Supplementary Figure S3, phosphatase activity was detected in both $\mathrm{M} 9$ and Hepes media. At alkaline $\mathrm{pH}$, phosphatase activity was 2.14-fold higher in the absence of Pi (i.e. Hepes medium), than in its presence (M9 medium).

\section{Effect of AMP-CPP on ATPase activity}

AMP-CPP, a non-hydrolyzable ATP analog, was used as a potential inhibitor of ATPase activity. AMP-CPP is expected to permeate the OM since it is structurally similar to ATP but smaller than the 600-700 Da cut-off size for the permeability of main E. coli porins [54]. Bacterial suspensions were exposed to $600 \mathrm{nM}$ ATPe both in Hepes and M9 media (Figure 3A). In media with or without AMP-CPP, ATPase activity in the Hepes medium was higher than that in the M9 medium. With $100 \mu \mathrm{M}$ AMP-CPP, ATPase activity was reduced by approximately 60\% (Hepes medium) and 82\% (M9 medium) (Figure 3B).

\section{ATPe uptake and ATPase activity}

The results above show that exogenous ATP can be hydrolyzed by E. coli. Since enzymes promoting ATPe hydrolysis are located in the periplasm, we checked whether ATPe can be incorporated into bacteria. Aliquots of E. coli suspensions were incubated with $1 \mu \mathrm{M}\left[\gamma_{-}{ }^{32} \mathrm{P}\right] \mathrm{ATP}$ for 2 or $30 \mathrm{~min}$ in the M9 medium, after which they were diluted and centrifuged to obtain a pellet. This pellet was then used to determine both the total amount of radioactivity incorporated and, in separate samples, the proportion of this radioactivity due to either $\left[\gamma^{32} \mathrm{P}\right] \mathrm{ATP}$ or $\left[\gamma^{32} \mathrm{P}\right] \mathrm{Pi}$ content.

Since M9 has millimolar concentrations of $\mathrm{Pi}$, any $\mathrm{nM}\left[\gamma_{-}{ }^{32} \mathrm{P}\right] \mathrm{Pi}$ accumulated in the extracellular medium will be highly diluted in unlabeled $\mathrm{Pi}$, making direct $\left[\gamma^{32} \mathrm{P}\right] \mathrm{Pi}$ uptake into the periplasm negligible. In the bacterial pellet, $\left[\gamma_{-}{ }^{32} \mathrm{P}\right]$ ATP and $\left[\gamma_{-}{ }^{32} \mathrm{P}\right] \mathrm{Pi}$ were 1.5 - and 2 -fold higher at $30 \mathrm{~min}$ than at $2 \mathrm{~min}$ (Figure 1C), suggesting $\left[\gamma_{-}{ }^{32} \mathrm{P}\right]$-ATP uptake into the periplasm, with subsequent release of $\left[\gamma_{-}{ }^{32} \mathrm{P}\right] \mathrm{Pi}$.

For each incubation time, the relative proportion of $\left[\gamma_{-}{ }^{32} \mathrm{P}\right] \mathrm{Pi}$, with respect to $\left[\gamma_{-}{ }^{32} \mathrm{P}\right] \mathrm{ATP}$, was similar. Total radioactivity of the pellets was not significantly different from the sum of the radioactivity obtained with $\left[\gamma^{32} \mathrm{P}\right] \mathrm{Pi}+\left[\gamma^{32} \mathrm{P}\right] \mathrm{ATP}$ (Supplementary Figure $\mathrm{S} 4$ ). 


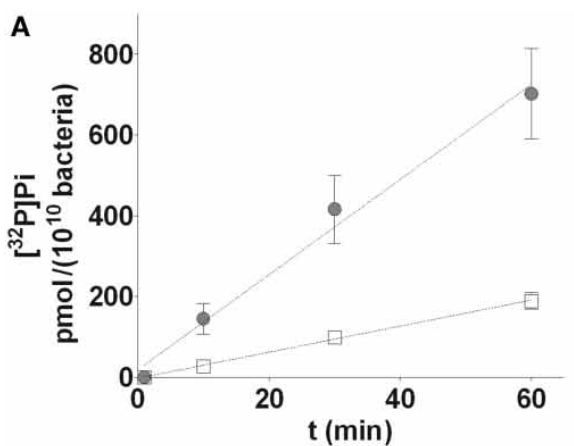

$600 \mathrm{nM}$
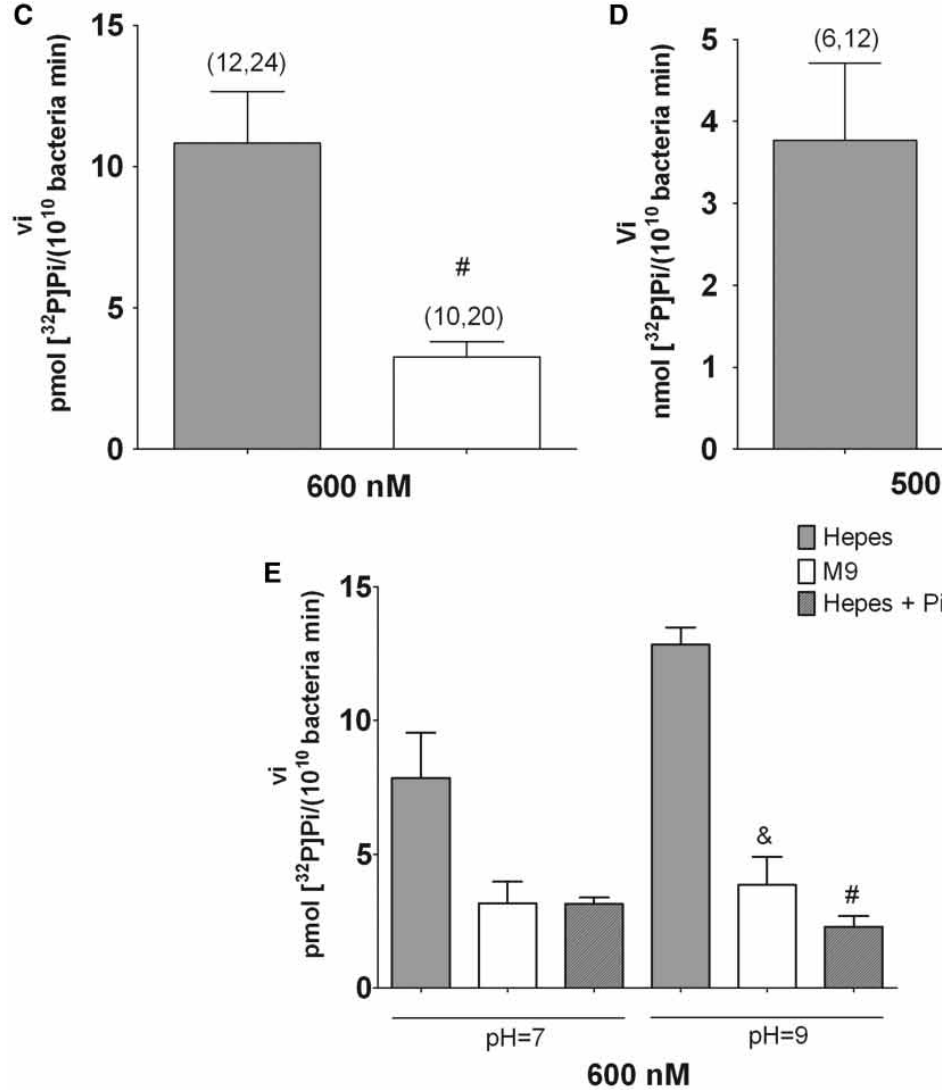

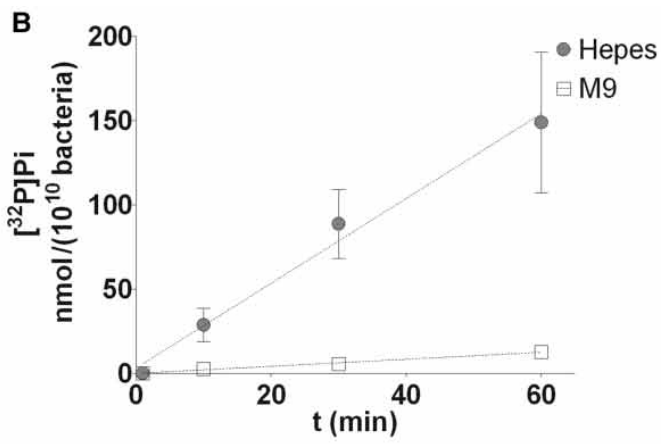

$500 \mu \mathrm{M}$

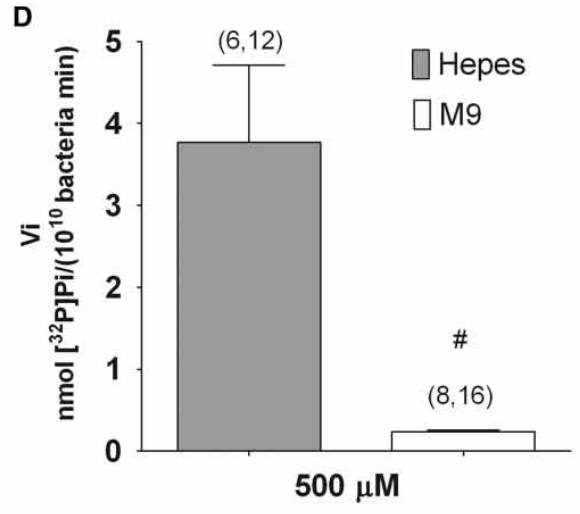

$\square$ Hepes 

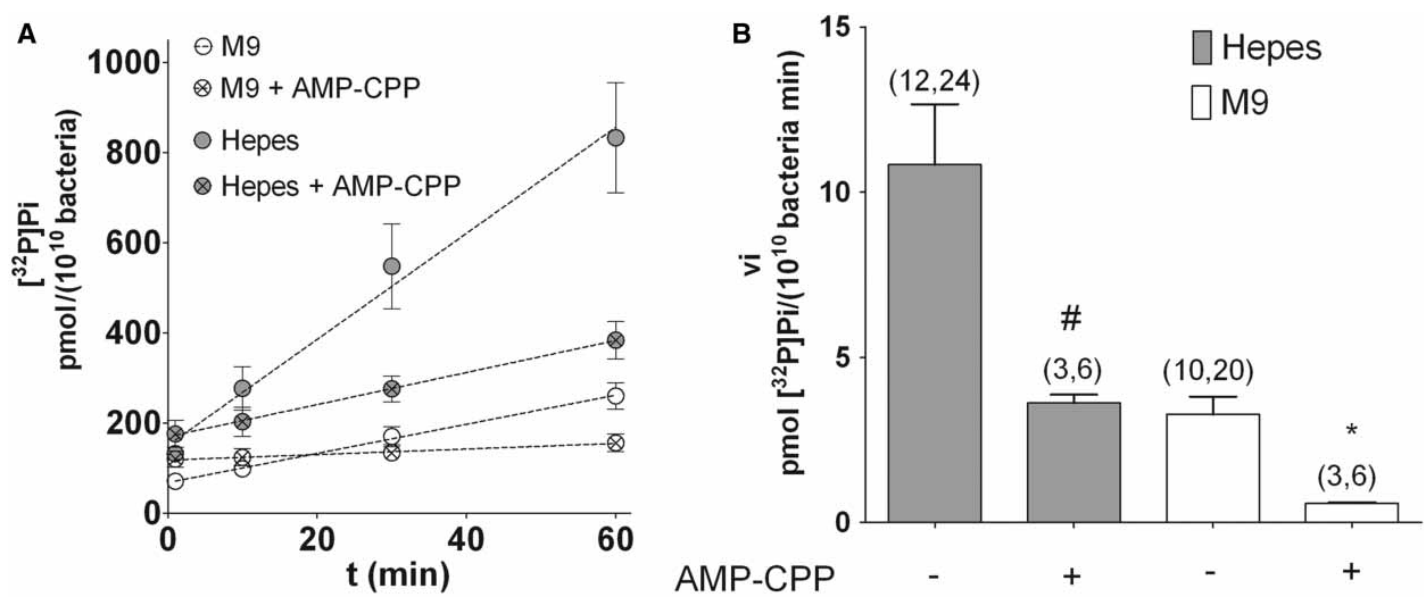

Figure 3. Effect of AMP-CPP, a non-hydrolyzable ATP analog, on ATPase activity of $E$. coli.

(A) Time course of [ $\left[{ }^{32} \mathrm{P}\right] \mathrm{Pi}$ accumulation released from $600 \mathrm{nM}\left[\gamma^{-32} \mathrm{P}\right] \mathrm{ATP}$, using $E$. coli suspended in media with $\mathrm{Pi}$ (M9) or without Pi (Hepes), in the absence or presence of $100 \mu \mathrm{M}$ AMP-CPP (left). The dotted lines represent the fit of linear functions to experimental data. (B) ATPase activity (vi) derived from Pi kinetics of $\mathbf{A}$. Results are expressed as pmol $\left[{ }^{32} \mathrm{P}\right] \mathrm{Pi} /\left(10^{10} \mathrm{bacteria}\right.$ $\mathrm{min})$ and are means \pm SEM. $\left({ }^{*} P<0.05 ;{ }^{\#} P<0.001\right)$. Number of replicates $(n)$ and independent experiments $(N)$ are given in brackets on top of the bars $(N, n)$.

\section{ATPe kinetics}

In Figure 4A,B, the ATPe kinetics from E. coli is shown, which depends on both the rates of ATP release (promoting an increase in [ATPe]) and ATPe hydrolysis (promoting a decrease in [ATPe]).

In the absence of stimuli, [ATPe] remained steady at $24 \pm 3 \mu \mathrm{M} /\left(10^{10}\right.$ bacteria $)$.

ATP release was then stimulated by adding MST7 and MEL. These amphipatic peptides can act as permeabilizing agents, compromising bacterial integrity to different extents. Thus, in principle, peptides may trigger ATP release by lytic and non-lytic mechanisms. With $10 \mu \mathrm{M}$ MST7, an acute 3-fold increase in [ATPe] was observed, followed by a phase of slower increase. Ten $\mu$ M MST17, an inactive analog of MST7, produced no effect (Figure 4A).

Both 3 and $30 \mu \mathrm{M}$ MEL (denoted as MEL3 and MEL30, respectively) caused acute ATP release of different magnitudes. Under MEL3, a 1.4-fold increase in [ATPe] was observed within $1 \mathrm{~min}$, which remained constant thereafter. On the other hand, MEL30 produced a fast 5 -fold increase in [ATPe] within $1 \mathrm{~min}$, followed by a phase of slower increase (Figure $4 \mathrm{~B}$ ). Values of $\triangle \mathrm{ATP}_{20}$, i.e. values of [ATPe] attained at $20 \mathrm{~min}$ post-stimulus for each treatment, are shown as insets of Figure $4 \mathrm{~A}, \mathrm{~B}$.

To illustrate the transient nature of ATP release, Figure $4 \mathrm{C}$ shows the results obtained by taking the first derivative of ATPe kinetics from Figure 4A,B. In this way, the instantaneous changes of [ATPe], an indicator of bacterial ATP permeability $\left(\mathrm{P}_{\mathrm{ATP}}\right)$, could be observed. Both for MST7 and MEL30, an acute steep increment of $\mathrm{P}_{\mathrm{ATP}}$, amounting to 53 (MST7) and 155 (MEL30) $\mu \mathrm{M} \mathrm{ATP} /\left(10^{10}\right.$ bacteria min) was followed by a slower exponential decay.

Intracellular ATP content (ATPi) amounted to $296 \pm 78 \mu \mathrm{M}$ ATP $/\left(10^{10}\right.$ bacteria). This means that $\Delta \mathrm{ATP}_{20}$ values (i.e. the increase in [ATPe] at 20 min post-stimulus) for MST7, MEL3, and MEL30 represented 22.3, 5.5, and $87.4 \%$ of ATPi, respectively.

\section{Viability}

The observed MEL- and MST7-dependent ATPe kinetics in Figure 4 could be induced by lytic and/or non-lytic release of ATPi. Therefore, we analyzed the effects of these peptides on the ability of bacteria to form colony units (CFU) and the IM integrity. The latter was measured in transformed E. coli BL21 expressing $\beta$-galactosidase, in the presence of ONPG.

Formation of colonies on a plate (denoted as culturability) does not necessarily reveal the viability of bacteria under assay conditions but rather shows that there were bacteria in the sample that, after the different treatments, were able to grow and divide. 

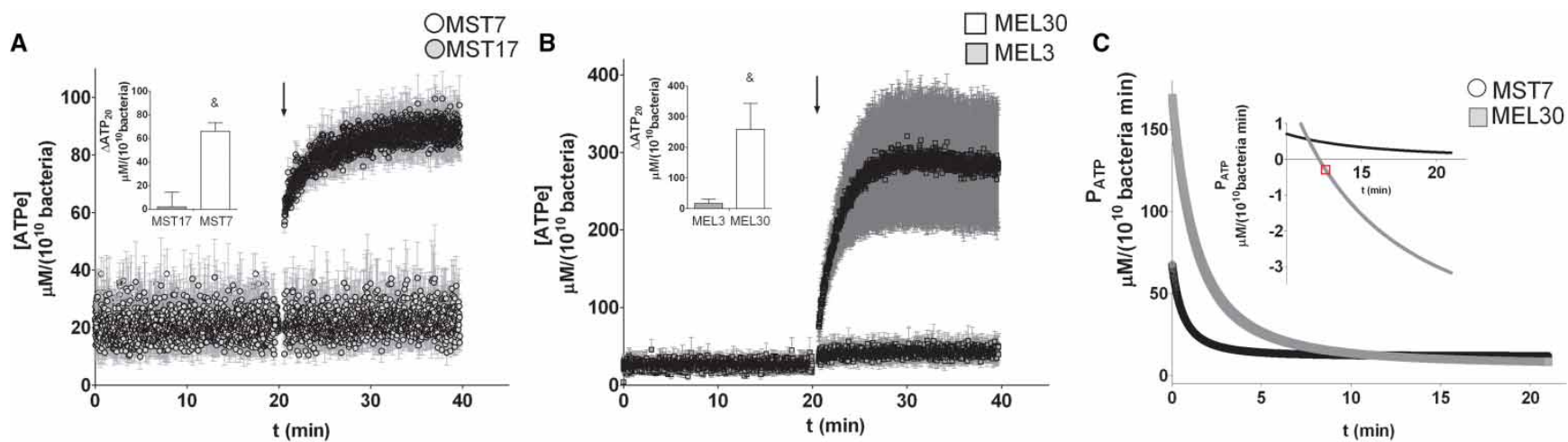

Figure 4. ATPe content, kinetics, and permeability of $E$. coli suspensions exposed to mastoparan 7 and melittin.

(A,B) Effects of the peptides mastoparan 7 (MST7) and its inactive analog mastoparan 17 (MST17) (A) or melittin (MEL, B), on ATPe kinetics from E. coli suspended in the M9 medium. At the time indicated by the arrow, bacterial suspensions were exposed to: $\mathrm{A}$. $10 \mu \mathrm{M}$ of MST7 $(\mathrm{N}=12, n=16)$ and MST17 ( $N=5, n=7$ ); B. $3 \mu \mathrm{M}$ MEL (MEL3, $N=5, n=5$ ) or $30 \mu \mathrm{M}$ MEL (MEL30, $N=7, n=7)$. Levels of ATPe were expressed as $\mu \mathrm{M} /\left(10^{10}\right.$ bacteria). Data represent mean values \pm SEM. Insets of Figure $A, B$ : data of $A$ and $B$ were used to calculate the increase in [ATPe] at 20 min post-stimulus. Values are expressed as $\triangle \mathrm{ATP}_{20}\left[\mu \mathrm{M} /\left(10^{10}\right.\right.$ bacteria)], i.e. the difference between [ATPe] at 20 min post-stimulus and basal [ATPe]. Results are means \pm SEM. ( $\left.{ }^{\&} P<0.01\right)$. (C) Data of $A$ and $B$ were used to calculate the effects of MST7 and MEL30 on ATP permeability $\left(P_{\text {ATP }}\right)$. Values are expressed as $\mu \mathrm{M} /\left(10^{10}\right.$ bacteria min). Inset: a detail of the last $5 \mathrm{~min}$ of the experiments. For the MEL30 curve, the red dot indicates the time point when ATPe decay equals ATPase activity (vi) derived from Figure 1B at $290 \mathrm{nM}$.

MST7 and MEL3 decreased CFU formation by approximately 30\% (Supplementary Figure S5). In both cases the effects were acute, since for each peptide, CFU values after $1 \mathrm{~min}$ exposure were not statistically different from those obtained after $20 \mathrm{~min}$. MST17 did not change CFU values. Exposure to MEL30, on the other hand, decreased CFU values by 57 and $79 \%$ at 1 and 20 min, respectively (Supplementary Figure S5A).

The $\beta$-galactosidase assay showed similar activity values for control and MST17-treated samples. While exposure to MST7 or MEL3 caused no changes in $\beta$-galactosidase activity, under MEL30, a different pattern was observed. In this case, low increments in activity at relatively low incubation times $(0-5 \mathrm{~min})$ were followed by strong increases, of approximately 5.6-fold, at later times (5-20 min) (Supplementary Figure S5B,C). Thus, except for MEL30, the observed decrease in culturability using MST7 and $3 \mu \mathrm{M}$ MEL occurs without viability (as assayed by $\beta$-galactosidase activity) being compromised.

\section{OMVs}

OMVs originate from E. coli under culture. Following purification, OMVs were detected by electron microscopy as spherical vesicles with diameters ranging from 50 to $200 \mathrm{~nm}$, surrounding an electrodense center (Figure 5A), as previously described [55,56].

TLC analysis showed that OMVs were composed of LPS, PE, and CL (Figure 5B), the main phospholipid classes present in the OM of Gram-negative bacteria.

As, during formation, OMVs encapsulate portions of the bacterial periplasm with soluble proteins, they might exhibit ATPase activity due to originally periplasmic nucleotidases and phosphatases. Moreover, if significant ATP amounts were present in the vesicles' lumen, then this pool might be released by MEL and MST7 exposure. Accordingly, as with E. coli, ATPase activity and ATPe kinetics of OMVs were studied.

\section{ATPase activity}

ATPase activity of OMVs was obtained by real-time luminometry after the addition of ATP. Figure 5C shows a steady pre-stimulus ATPe level, followed by an acute increase when ATP was added. The subsequent kinetics of [ATPe] decrease could be used to estimate ATPase activity (see the 'ATPe hydrolysis by real-time luminometry' section in M\&M) at each [ATPe], from which a substrate curve could be built (Figure 5D). Such a curve showed ATPase activity increased with [ATPe]. Moreover, the determination of ATPase activity using $\left[\gamma^{32} \mathrm{P}\right]$-ATP at a single [ATPe] provided similar results (see Figure 5D and Supplementary Figure S6). 
A

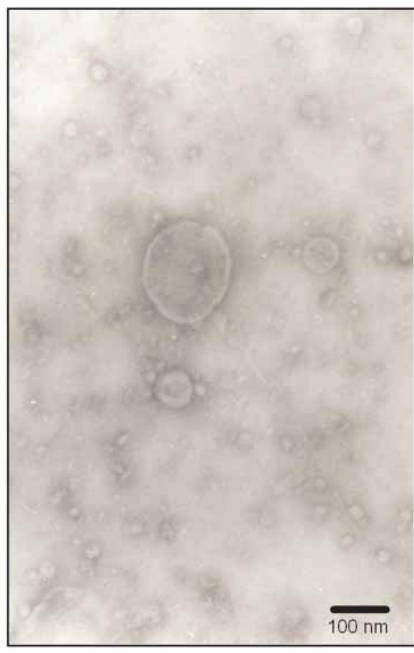

B

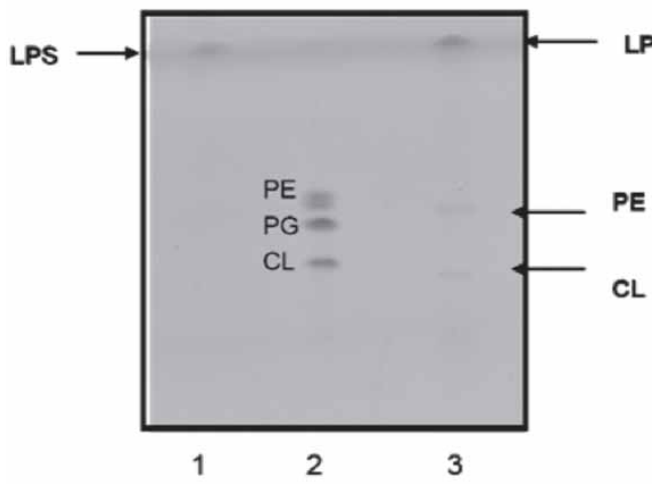

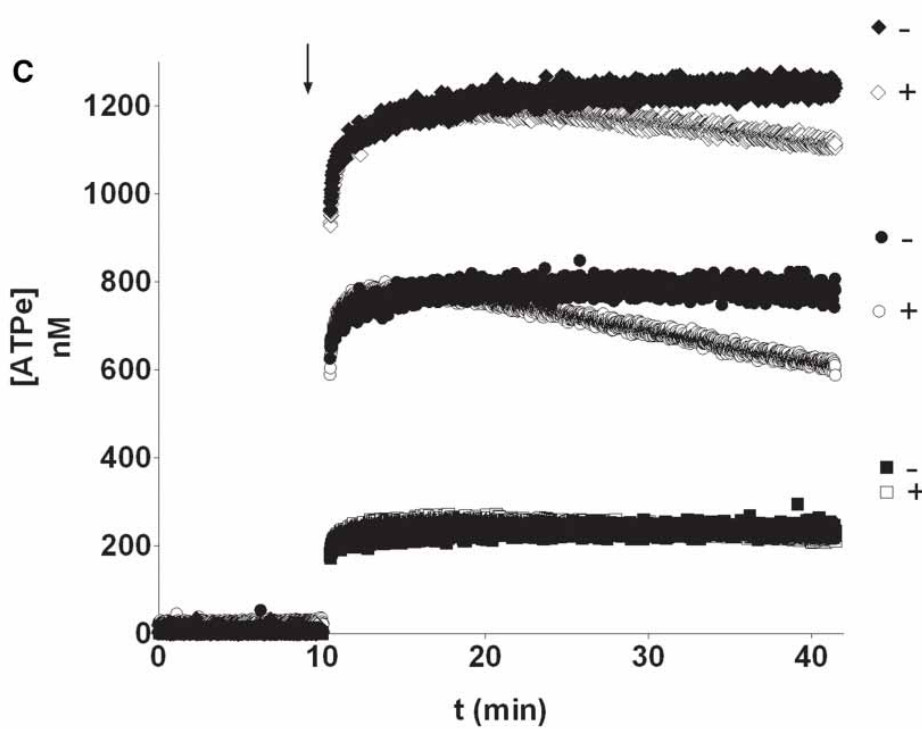

D $\mathrm{K}_{\mathrm{ATP}}=0.00165 \pm 0.00034[1 /(\mu \mathrm{g} \operatorname{prot} \mathrm{min})]$

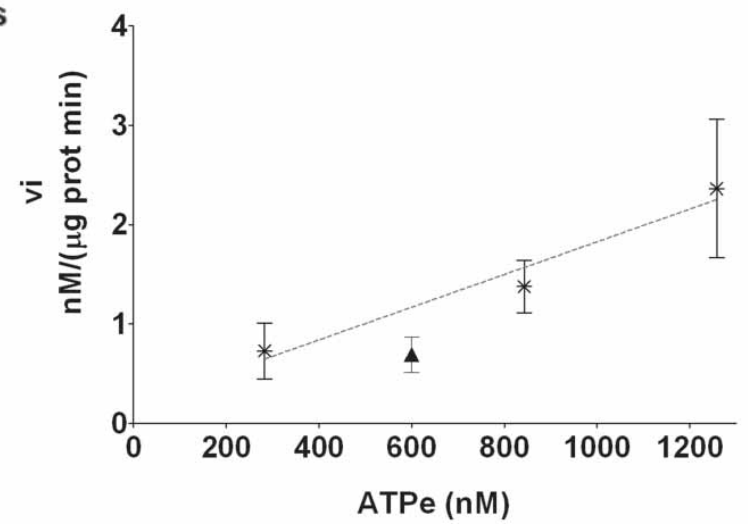

Figure 5. Outer Membrane Vesicles (OMVs) from E. coli. Morphology, lipid composition, ATPe kinetics, and ATPase activity. (A) Electron micrographs $(50000 \times)$ of OMVs. Scale bars are $100 \mathrm{~nm}$. (B) Thin layer chromatography of OMVs. 1: LPS extracted from E. coli; 2: standard lipids: phosphatidylglycerol (PG), cardiolipin (CL), and phosphatidylethanolamine (PE) and 3: total lipids extracted from OMVs. (C) ATPase kinetics of OMVs exposed to exogenous ATP. Experiments were run in the presence of OMVs (white symbols) or controls in their absence (solid symbols). At the time indicated by the arrow, ATP was added at $200 \mathrm{nM}(\square, N=4, n=4), 600 \mathrm{nM}(\bigcirc, N=6, n=6)$, and $1000 \mathrm{nM}(\oslash, N=5, n=5)$. Levels of ATPe were expressed as $\mathrm{nM}$ for $\mu \mathrm{g}$ OMVs suspended in $100 \mu \mathrm{l}$ assay medium (0.8-1.4 $\mu \mathrm{g}$ protein per experiment). +: with OMVs; -: without OMVs. Mean values are shown. (D) ATPase activity as $\mathrm{nM} /(\mu \mathrm{g}$ prot $\mathrm{min}$ ) of OMVs. Each symbol was calculated from the initial rate of [ATPe] decay taken from data of $\mathrm{C}$. ATPe values of the abscisa result from the sum of endogenous + exogenous ATP. The dotted line is a fit of a linear function to experimental data, with KATP being the slope of the substrate curve. The solid triangle represents a result from an independent experiment (data of Supplementary Figure S6) where ATPase activity was determined by following the time course of $\left[{ }^{32} \mathrm{P}\right] \mathrm{Pi}$ released from $\left[\gamma^{32}{ }^{32} \mathrm{P}\right] \mathrm{ATP} 600 \mathrm{nM}$. Results are means \pm SEM. $n, N$ denote number of replicates $(n)$ and independent experiments $(N)$.

\section{ATPe kinetics}

In the absence of stimuli, [ATPe] of OMVs amounted to $13 \pm 5 \mathrm{nM} /(\mu \mathrm{g}$ protein). Under MST7 exposure, a 3 fold-increase in [ATPe] was observed within $1 \mathrm{~min}$, followed by a phase of slower increase. Exposure to MEL30 caused an acute 7 fold-increase in [ATPe], followed by a continuous increasing phase (Figure 6). At more prolonged exposure times, [ATPe] decreased due to ATPase activity (Supplementary Figure S7). Values of $\triangle \mathrm{ATP}_{20}$ showed a 4-fold higher [ATPe] for MEL30 than for MST7 (inset of Figure 6). 


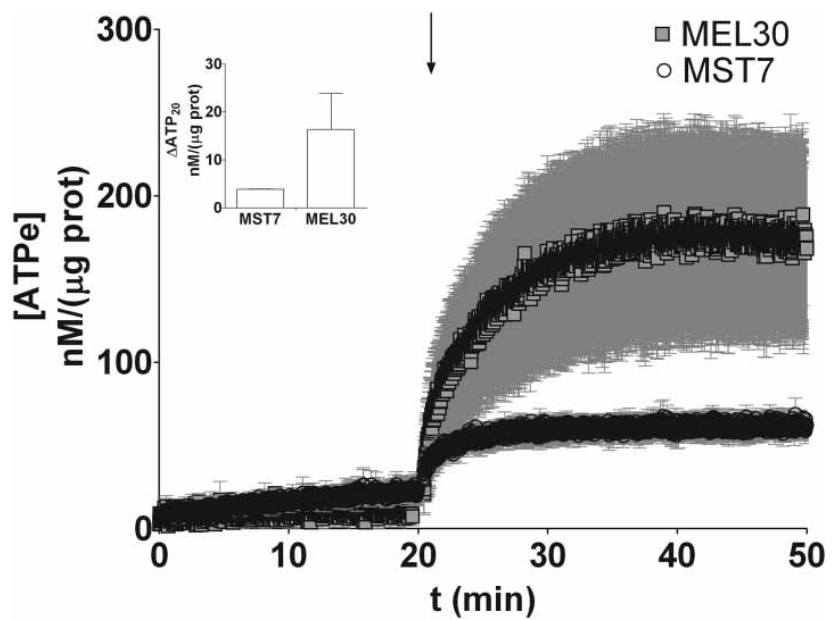

Figure 6. ATPe kinetics of mastoparan 7- and melittin-treated OMVs.

The time course of [ATPe] was quantified by real-time luminometry, similarly to Figure 4. At the time indicated by the arrow, OMVs were exposed to $10 \mu \mathrm{M}$ MST7 or $30 \mu \mathrm{M}$ melittin (MEL30). Levels of ATPe were expressed as nM/( $\mu \mathrm{g}$ prot). Data represent mean values \pm SEM $(N=2, n=6)$. Experiments in which OMVs were exposed to $30 \mu \mathrm{M}$ melittin for more prolonged times are shown in Supplementary Figure S7. Inset: data were used to calculate the increase in [ATPe] at 20 min post-stimulus. Values are expressed as $\Delta \mathrm{ATP}_{20}[\mathrm{nM} /(\mu \mathrm{g}$ prot)], i.e. the difference between [ATPe] at 20 min post-stimulus and basal [ATPe]. $n, N$ denote number of replicates $(n)$ and independent experiments $(N)$.

The OMV is a much simpler system than $E$. coli. Vesicles have a single internal compartment containing ATP, and mechanisms enabling ATP synthesis do not exist. On the other hand, the periplasmic ATP of E. coli can be influenced by cytosolic ATP (produced by an ATP synthase) as well as ATPe. Despite these differences, we tested whether ATPe kinetics of OMVs may mimic that of bacteria.

Accordingly, ATPe kinetics of OMVs and E. coli exposed to MST7 and MEL30 were compared by means of a correlation plot. Results showed a linear relationship for [ATPe] values of E. coli and OMVs for at least $5 \mathrm{~min}$, although at later times this linearity was lost (Supplementary Figure S8A,B).

\section{Caco-2 cells}

Our results have shown that E. coli is capable of ATPe uptake and hydrolysis and, in the presence of amphipatic peptides, the release of intracellular ATP. Since in vivo E. coli may metabolically interact with intestinal epithelial cells of the human host, we evaluated the effect of E. coli on ATPe kinetics of Caco-2 cells, a model of epithelial enterocytes, and the potential effect of $E$. coli on these kinetics.

Caco-2 cells were grown as a polarized epithelial cell monolayer. ATPe kinetics was quantified on the apical side using real-time luminometry (Supplementary Figure S2).

In the absence of bacteria, Caco- 2 cells showed a basal rate of ATPe decrease amounting to $0.03 \pm 0.003 \mathrm{nM} /$ min. The addition of exogenous ATP $(1.4-7 \mu \mathrm{M})$ led to an acute [ATPe] increase, followed by a decay phase (Figure 7A). The resulting decay kinetics were used to estimate ATPase activity. This was a linear function of [ATPe] over an ample $\mathrm{nM}-\mu \mathrm{M}$ range (Figure $7 \mathrm{~B}$ ), with the slope of the curve $\left(K_{\mathrm{ATP}}\right)$ amounting to $0.023 \mathrm{~min}^{-1}$ for approximately $5 \times 10^{5}$ cells per well. Rates of ATPe hydrolysis, by assessing ${ }^{32} \mathrm{P}-\mathrm{Pi}$ production, provided similar results (Supplementary Figure S9).

Next, we determined the effect of $E$. coli and $3 \mathrm{~V}$ on ATPe kinetics of Caco-2 cells. $3 \mathrm{~V}$ is an adrenergic cocktail that can trigger ATP release via elevation of cAMP [38,50,57]. Experiments were run in the absence and presence of carbenoxolone (CBX), a generic blocker of ATP release of most eukaryotic cells [46,32]. Accordingly, stimuli were added to the apical medium and ATPe kinetics of Caco- 2 cells was determined.

In the absence of stimuli, [ATPe] of Caco-2 cells amounted to $123 \pm 5 \mathrm{nM}$ (Figures 7C,D). Addition of 3V (Figure 7C) or E. coli $\left(2 \times 10^{7}\right.$ bacteria, Figure 7D) led to a 6 fold-increase in [ATPe] within 1 min to a maximum, followed by an acute decrease. These peaks were reduced $58-77 \%$ by CBX (inset Figure 7C,D), though the effect of CBX on $3 \mathrm{~V}$-induced ATP release was not significant $(P=0.12)$. 

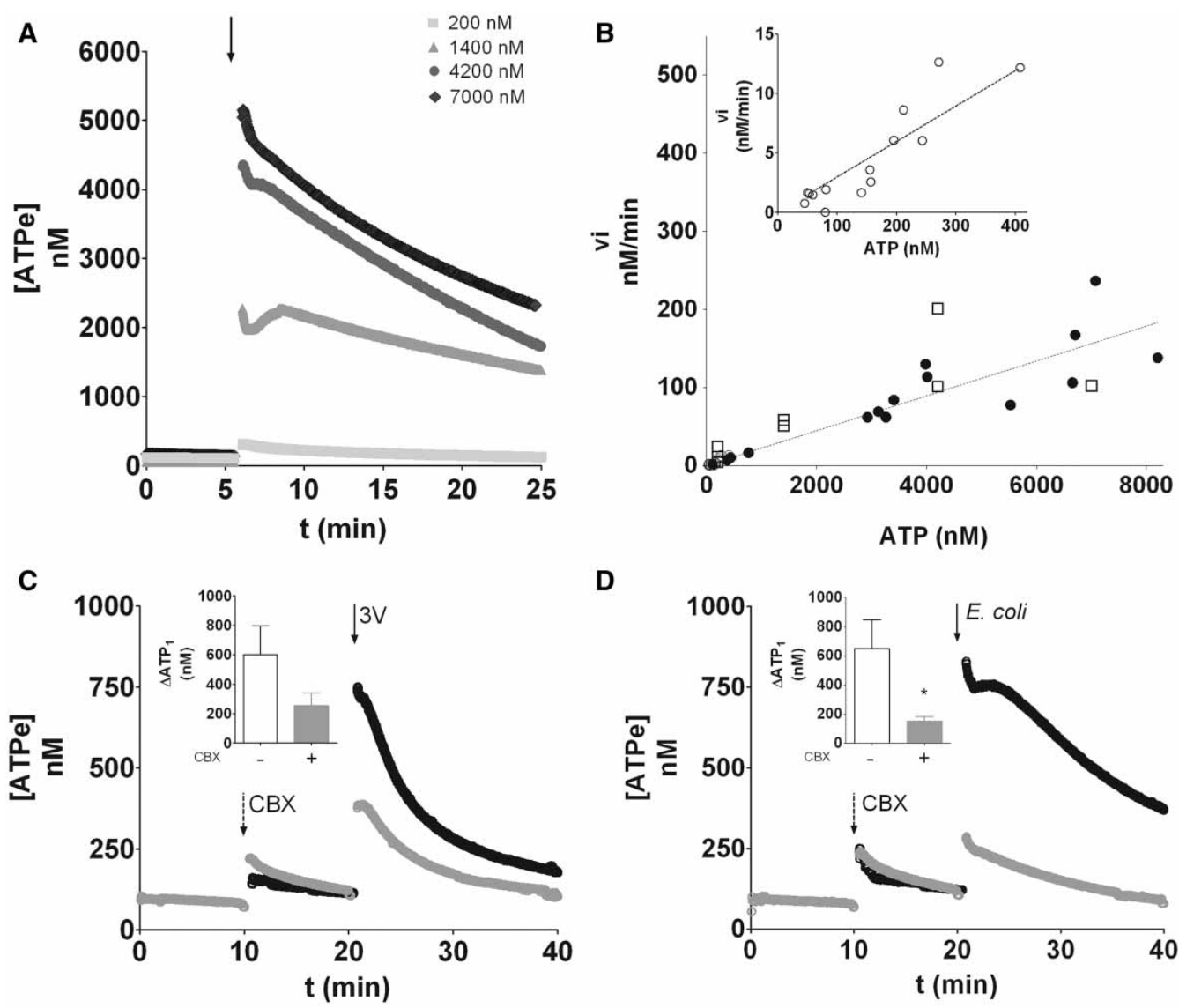

Figure 7. ATPe kinetics and ectoATPase activity of Caco-2 cells.

Assessment of ATPe kinetics by luminometry and ectoATPase activity by $\left[\gamma{ }^{3}{ }^{32} \mathrm{P}\right] \mathrm{Pi}$ production on the apical side of polarized Caco-2 cells. (A) ATPe kinetics of cells exposed to exogenous ATP (200-7000 nM). Levels of ATPe are mean values expressed as $\mathrm{nM}$ for approximately $5 \times 10^{5}$ cells incubated in $40 \mu \mathrm{l}$ of apical medium $(N=3-6)$. (B) ATPase activities (vi) were estimated from ATPe decay kinetics using data from A (circles), or from $\left[{ }^{32} \mathrm{P}\right] \mathrm{Pi}$ production from [ $\left.\gamma_{-}{ }^{32} \mathrm{P}\right] \mathrm{ATP}$ (squares), using data from Supplementary Figure S9. Results are expressed as nM/min. Open and closed circles represent vi values calculated from ATPe kinetics in the absence and presence of exogenous ATP, respectively. The dotted line represents the fitting of a linear function to experimental data. The inset shows the detail of the low range of ATPe concentrations (0-400 nM). (C) ATPe kinetics of cells exposed to the adrenergic cocktail $3 \mathrm{~V}$ ( $30 \mu \mathrm{M}$ forskolin, $100 \mu \mathrm{M}$ papaverine, $10 \mu \mathrm{M}$ isoproterenol). Experiments were run in the absence (black lines) and presence (gray lines) of $100 \mu \mathrm{M}$ carbenoxolone (CBX). Levels of ATPe are mean values expressed as $\mathrm{nM}(N=11)$. (D) ATPe kinetics of cells exposed to $E$. coli suspensions. Experiments were run in the absence (black lines) and presence (gray lines) of $100 \mu \mathrm{M}$ CBX. Levels of ATPe are mean values expressed as nM $(N=10-12)$. Insets of Figure C,D. Apical ATPe levels taken from data of $\mathbf{C}$ and $\mathbf{D}$. Values are expressed as $\triangle \mathrm{ATP}_{1}$, i.e. the difference between [ATPe] at $1 \mathrm{~min}$ post-stimulus and basal $[A T P e]$. Results are means \pm SEM $\left({ }^{*} P<0.05\right)$. Each filter containing polarized monolayers of Caco-2 cells was considered an independent preparation $(N)$.

\section{Intestinal rat segments}

Bacterial suspensions were perfused through the lumen of jejunum rat segments. These conserved the intestinal wall structure and could therefore exhibit smooth muscle contractions that might influence ATP release. Luminal $\mathrm{ATP}_{\mathrm{L}}$ was monitored by off-line luminometry.

In the absence of bacteria $\left[\mathrm{ATP}_{\mathrm{L}}\right]$ remained steady for $90 \mathrm{~min}$ at $13 \pm 2 \mathrm{nM}(N=2$, Supplementary Figure S10).

Then, $\mathrm{ATP}_{\mathrm{L}}$ was measured in perfusate samples in the absence of bacteria for $30 \mathrm{~min}$ at $10 \mathrm{~min}$ intervals. Subsequently, the Ringer solution was replaced by a bacterial suspension containing $5 \times 10^{8}$ bacteria/ml and 

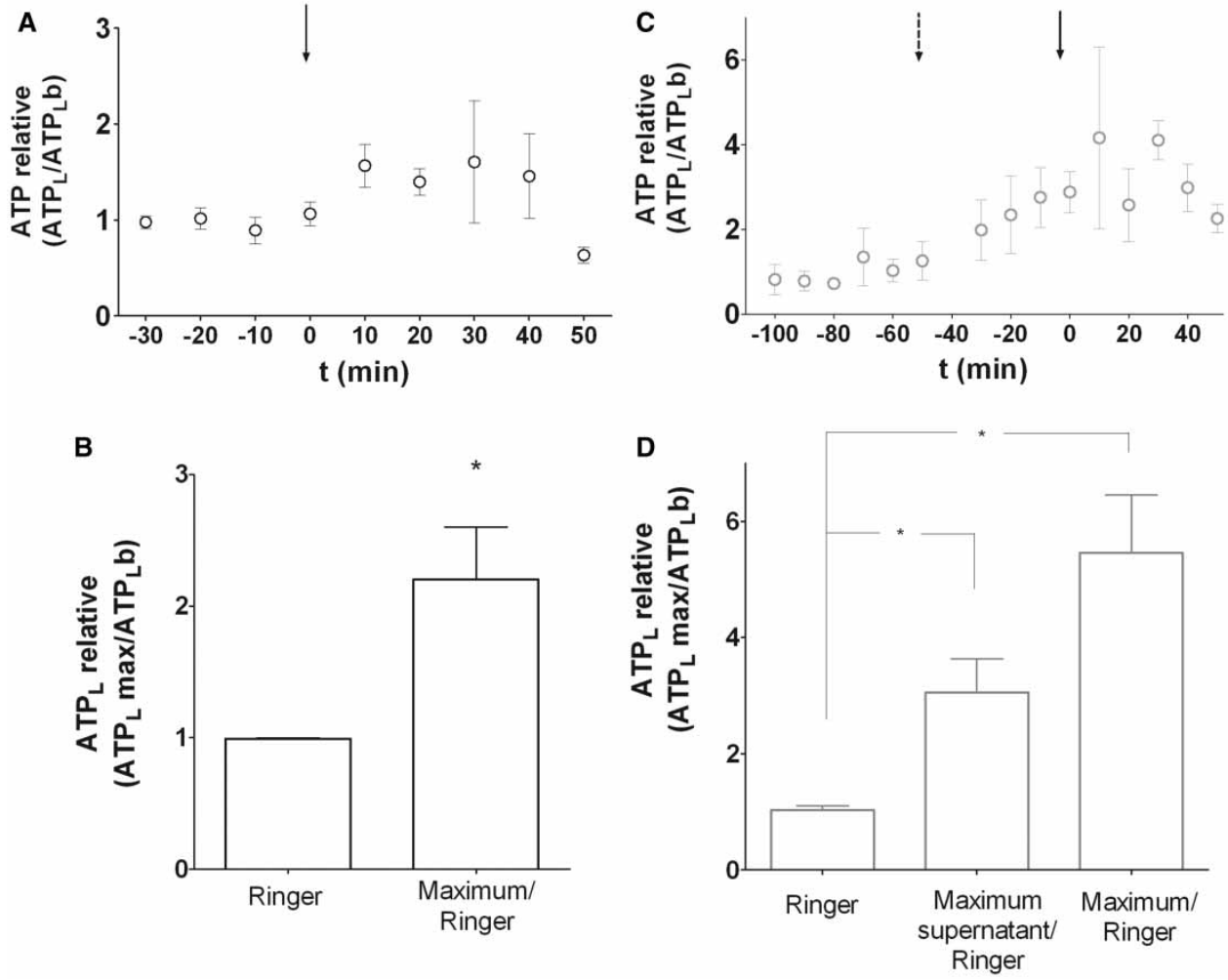

Figure 8. Luminal ATP contents of rat intestinal segments.

(A) The time course of luminal ATP (ATPL) from rat jejunum segments was followed by off-line luminometry. At the time indicated by the arrow, bacterial suspensions (final concentration $5 \times 10^{8}$ bacteria/ml) were perfused in rat intestinal segments.

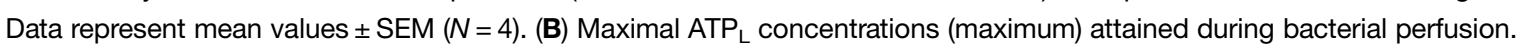
Values were normalized with respect to control ATP $\mathrm{L}_{\mathrm{L}}$ values (basal) in the absence of bacteria $(P<0.05, N=4)$. (C) The time course of luminal ATP $\left(A T P_{L}\right)$ from rat jejunum segments was followed by off-line luminometry. At the time indicated by the dashed line arrow, supernatants collected from $E$. coli suspensions were perfused in intestinal segments. The continuous arrow represents the time at which bacterial suspensions were perfused (final concentration $5 \times 10^{8} \mathrm{bacteria} / \mathrm{ml}$ ). Data represent mean values \pm SEM $(N=3)$. (D) Maximal ATP concentrations attained during supernatant (maximum supernatant) and bacterial (maximum) perfusion. Values were normalized with respect to control $\mathrm{ATP}_{\mathrm{L}}$ values (Ringer) $\left({ }^{\star} P<0.05\right)$. Each segment was considered an independent preparation $(N)$.

$\mathrm{ATP}_{\mathrm{L}}$ was measured every $10 \mathrm{~min}$ during the next $60 \mathrm{~min}$ (Figure 8A). Compared with basal pre-stimulated $\mathrm{ATP}_{\mathrm{L}}$ values, $E$. coli suspensions induced a 2 -fold increase in the $\mathrm{ATP}_{\mathrm{L}}$ maximal value which was determined within the 30 min exposure to bacterial perfusion $(P<0.05$, Figure $8 \mathrm{~B}, N=4)$. After $40 \mathrm{~min}, \mathrm{ATP}_{\mathrm{L}}$ decreased to basal pre-stimulated levels (Figure 8A).

Next, we checked whether the observed increased in $\operatorname{ATP}_{L}$ was caused by the ATPe content of the bacterial suspension. Thus, bacterial suspensions were centrifuged and the supernatant was collected. Intestinal segments were then perfused with Ringer solution, followed by the bacterial supernatant, and finally, the bacterial suspension (Figure $8 \mathrm{C}$ ). Results show that maximal $\mathrm{ATP}_{\mathrm{L}}$ levels, compared with basal values, were 3 -fold and 5 -fold higher with the bacterial supernatant and the bacterial suspension, respectively (Figure 8D). This means that endogenous ATPe of bacteria, as well as bacteria themselves, cause increases of $\mathrm{ATP}_{\mathrm{L}}$ levels.

\section{Discussion}

The results of the present study show that ATPe regulation in E. coli results from a dynamic balance between the rates of ATP release and ATPe hydrolysis. Moreover, we show that OMVs, produced and released by E. coli under standard growth conditions, retain key features of the processes mediating ATPe regulation in bacteria. 
In addition, we found that E. coli can strongly enhance ATPe release of Caco-2 cells and intestinal rat segments.

\section{Studies using E. coli and OMVs}

The addition of exogenous ATP to bacterial suspensions, which should promote ATP transport through OM porins into the periplasm [4,7], led to significant ATPe uptake and hydrolysis.

ATPase activity increased in proportion to [ATPe] over a wide nanomolar range (Figure 1B). A similar pattern was observed in OMVs, which is consistent with these vesicles encapsulating portions of the bacterial periplasm containing functional enzymes [44].

Based on previous reports [5,15] we propose periplasmic 5 -nucleotidase and alkaline phosphatase to be responsible for the observed ATPe hydrolysis at neutral $\mathrm{pH}$. To further corroborate the functional presence of these enzymes, we evaluated the effect of medium Pi. 5'-nucleotidases from bacteria and various vertebrate species do not exhibit product inhibition $[15,58]$. Regarding alkaline phosphatase, although a transcriptional down-regulation of the enzyme in the presence of Pi was postulated, this mechanism was impeded under high Pi culture conditions. Nevertheless, several reports have showed that Pi can kinetically inhibit the alkaline phosphatase activity of $E$. coli $[18,59]$.

Thus, in addition to experiments using the M9 medium (containing $\mathrm{mM} \mathrm{Pi}$ ), we also evaluated ATPase activity in media lacking phosphate (i.e. Hepes medium), where a strong increase in ATPe hydrolysis was found. Two components of ATPe hydrolysis were observed, one of which is relatively insensitive to Pi, consistent with $5^{\prime}$-nucleotidase activity, and a second component which was kinetically inhibited by $\mathrm{Pi}$, and activated at alkaline $\mathrm{pH}$, consistent with alkaline phosphatase.

Since in both, E. coli and OMVs, ATPe hydrolysis was a linear function of [ATPe], any increase in the nucleotide will at least be partially down-regulated by increases of periplasmic (bacteria) or intravesicular (OMV) ATPase activity.

Having shown that periplasmic ATPase activity is active under the experimental conditions, we turned our attention to bacterial ATP release. This was estimated by studying ATPe kinetics in the absence and presence of two amphipatic peptides, MST7 and MEL. In unstimulated conditions, a stable nanomolar level of ATPe was observed (Figures $4 \mathrm{~A}, \mathrm{~B}$ ), which is compatible with a potential low rate of ATP release being counterbalanced by periplasmic ATPase activity.

In line with this idea, other authors found no ATP secretion by E. coli in the absence of stimuli [58]. Moreover, when expression of periplasmic $5^{\prime}$-nucleotidase and alkaline phosphatase of $E$. coli was blocked, ATP release could be observed in the absence of stimulus [5], a process that would lead to [ATPe] accumulation.

Basal [ATPe] was challenged when E. coli were perturbed by exposure to MST7 and MEL. Addition of the peptides caused a 3-fold (MST7) and 7-fold (MEL30) increase in [ATPe] within 1 min, with the amplitude of ATPe response at $20 \mathrm{~min}$ post-stimulus ranging from $66 \mu \mathrm{M} /\left(10^{10}\right.$ bacteria) (MST7) to $259 \mu \mathrm{M} /\left(10^{10}\right.$ bacteria) (MEL30). Changes in [ATPe] were achieved by triggering a strong initial rate of ATP release (denoted as $\mathrm{P}_{\text {ATP }}$ in Figure $4 \mathrm{C})$ under MST7 $(\approx 53 \mu \mathrm{M} / \mathrm{min})$ and MEL30 $(\approx 155 \mu \mathrm{M} / \mathrm{min})$. These rates were approximately 30 -fold higher than ATPase activities under the same conditions. Thus, the acute phase of ATPe kinetics mostly reflected the kinetics of ATP release. At later times, however, the rate of [ATPe] increase slowed down rapidly. While with MST7 a decrease in [ATPe] was not observed during 20 min exposure, with MEL30, [ATPe] started to decrease at approximately $12 \mathrm{~min}$ post-stimulus, an indication that ATP release is inactivated with time while ATPase activity progressively began to govern ATPe kinetics.

Overall, these results show that E. coli exhibit basal ATPe levels, which were greatly increased when bacteria were challenged by permeabilizers.

E. coli-derived ATPe may stimulate biofilm formation and adherence [60], promote bacterial growth, or even act as a quorum sensing signal [3].

Since bacterial ATP release can be caused by lytic and non-lytic mechanisms, two aspects of viability were analyzed, i.e. the capacity of bacteria to form colonies on solid agar plates (CFU) and the IM integrity, estimated by $\beta$-galactosidase activity.

Within $1 \mathrm{~min}, 10 \mu \mathrm{M}$ MST7 and $3 \mu \mathrm{M}$ MEL decreased CFU formation by approximately $30 \%$ (Supplementary Figure S5A), with no changes thereafter. Exposure to $30 \mu \mathrm{M}$ MEL produced a stronger decrease in CFU. $\beta$-galactosidase activity showed no changes with $10 \mu \mathrm{M}$ MST7 or $3 \mu \mathrm{M}$ MEL, while $30 \mu \mathrm{M}$ MEL produced a different pattern. In this case, low increments at short incubation times $(0-5 \mathrm{~min})$ were followed by strong increases at later times (5-20 min) (Supplementary Figure S5B). Thus MEL30, but not MST7, 
compromised the IM. In agreement with these findings, Katsu et al. [23] showed that MST perturbed the IM of E. coli only when the OM was previously disrupted [23]. Instead, MEL was able to disrupt both membranes in a dynamic fashion; it can assemble to form transient pores in the OM and then translocate to the IM, inducing the leakage of cytoplasmic contents [9].

Therefore, ATP efflux induced by MST7 was compatible with changes only in the permeability of the OM, suggesting ATP release from the periplasm, even though subsequent culture led to a decreased culturability.

Under MEL30, on the other hand, the acute phase of [ATPe] increase would be mostly non-lytic, followed by a later phase of increase where the IM is compromised, a condition where the ATPcyt content can be released, thus leading to the observed high amplitude of ATPe kinetics. Accordingly, after 20 min of MEL30 exposure, $87 \%$ of intracellular ATP was released by a combination of lytic and non-lytic mechanisms. The late decrease in [ATPe] could be due to the ATPase activity of periplasmic and cytoplasmic nucleotidases and phosphatases.

Thus, ATP is released by a combination of lytic and non-lytic mechanisms. Under partial bacteriolysis, dying bacteria might release ATP and other nucleotides, which can be taken up and metabolized by viable bacteria.

The ATPe kinetics of OMVs was qualitatively similar to that obtained with E. coli; [ATPe] remained steady in the absence of stimuli, and acutely increased in the presence of the peptides.

Values of [ATPe] at each time point from OMVs were compared with similar values from E. coli. This correlation plot (Supplementary Figure S8A,B) showed a roughly linear relationship for [ATPe] values of E. coli and OMVs for at least $5 \mathrm{~min}$ (the acute phase), although at later times this linearity was lost. This could be due to several reasons. First, OMVs are smaller than E. coli and as such represent a simpler system where, unlike whole bacteria, ATPe regulation can be studied in the absence of cytoplasmic content, that is, with no synthesis or release of ATPcyt. In addition, several authors reported that some OM proteins can be disproportionately enriched in OMVs, whereas others can be excluded, so that an altered capacity for the proteins involved in ATPe regulation may occur.

OMVs may contain DNA, and proteins exhibiting various biological activities [44], such as proteases, peptidases, and $\beta$-lactamases [61].

In this context we show that OMVs contain intravesicular ATP, and that, similarly to bacteria, this nucleotide can be released when vesicles are exposed to permeabilizers. This is important inasmuch as OMVs were shown to lyse when exposed to external stimuli [62] or open transiently [63].

Bacteria, and therefore OMVs, lack purinergic receptors (for extracellular di- and trinucleotides), so that signaling via these receptors is assumed to be absent from E. coli and other microorganisms [3]. Although speculative, OMVs, acting as delivery vesicles containing ATP and ATPases, might modulate the purinergic signaling system of the host.

Figure 9 provides a qualitative model of ATPe regulation of E. coli and their OMVs. Under culture conditions, OMVs are formed from E. coli. ATP can be present in the cytosol, the periplasm, the extracellular space, or the lumen of OMVs. In both, OMVs or bacteria, regulation of ATPe depends on the dynamic balance between the rates of ATP hydrolysis, facilitated by nucleotidases/phosphatases of the periplasm (E. coli) or vesicular lumen (OMVs) and of ATP release. Permeabilizers can act on the OM alone (MST7) or both on the outer and inner membrane (MEL).

\section{Effect of E. coli on the ATPe kinetics of Caco-2 cells}

Caco-2 cells have been previously shown to release ATP when exposed to hypotonicity [64]. Our results also showed regulated ATP release, in this case when cells were exposed apically to an adrenergic cocktail containing isoproterenol. This was not unexpected, since in these cells isoproterenol was shown to increase cAMP and $\mathrm{Ca}^{2+}$ [65,66], two well-known second messengers triggering ATP release in different cell types $[38,67,68]$, see Lazarowski [69]. ATPe concentration showed a fast and steep increase to a maximum, followed by a slower ATPe decay (Figure 7A). The latter is indicative of a high rate of extracellular ATPase activity, which could be corroborated by measuring ATPe consumption and ${ }^{32} \mathrm{P}-\mathrm{Pi}$ production under exposure to ATP (Supplementary Figure S9).

Thus, aliquots of $E$. coli were added to the apical side of Caco-2 cells, leading to a strong [ATPe] increase to a maximum, followed by an acute decrease (Figure 7D).

In Caco-2 cells, the initial rate of ATP release induced by E. coli (derived from data of Figure 7D), was approximately 30-fold higher than the rate of ATPe hydrolysis (Figure 7B) of these cells at similar ATPe levels. Therefore, during this brief phase of ATPe accumulation, quantified as $\triangle \mathrm{ATP}_{1}$ (inset of Figure $7 \mathrm{D}$ ), bacterial-induced ATPe kinetics was mainly governed by Caco-2 apical release of intracellular ATP. At later 


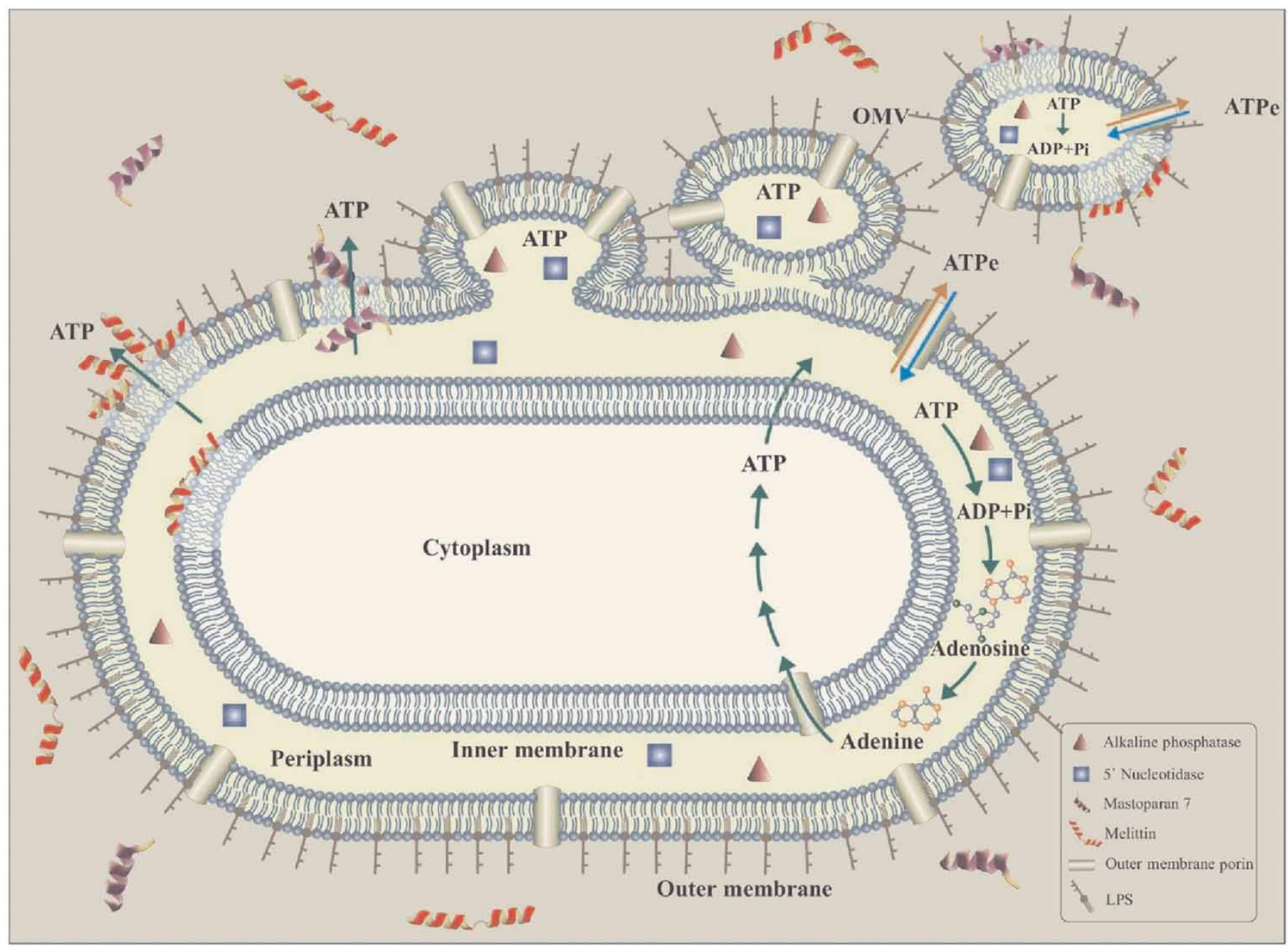

Figure 9. Qualitative model of ATPe regulation of $E$. coli and their outer membrane vesicles (OMVs).

Under normal growth conditions, OMVs are continuously formed from E. coli. These spherical vesicles form when small portions of the outer membrane bulge away from bacteria grown in broth, pinch off and release. ATP can be present in the cytosol, the periplasm, the extracellular space, or the lumen of OMVs. Permeabilizers can act on the OM alone (MST7) or both on the outer and inner membrane (MEL). E. coli was shown to hydrolyze ATPe and, in the presence of amphipatic peptides, release ATP. As, during formation, OMVs encapsulate portions of the bacterial periplasm with soluble proteins, they might exhibit ATPase activity due to originally periplasmic nucleotidases and phosphatases. In both, OMVs or bacteria, regulation of ATPe depends on the dynamic balance between the rates of ATP hydrolysis, facilitated by nucleotidases/phosphatases of the periplasm (E. coli) or vesicular lumen (OMVs), and of ATP release induced by MST7 and MEL.

times, however, [ATPe] decreased non-linearly, implying that ATPe release is down-regulated while ATPe hydrolysis began to dominate ATPe kinetics. Similarly, enteropathogenic E. coli-induced ATP release of TC7 epithelial cells, although the experimental set-up did not allow distinguishing the apical and basolateral components of ATP release [70].

What is the relative contribution of bacteria and Caco-2 cells to this late ATPe decay kinetics? Under the experimental conditions (Supplementary Figure S2), with approximately $5 \times 10^{5}$ Caco- 2 cells exposed to $2 \times 10^{7}$ E. coli, the corresponding values of $\mathrm{K}_{\mathrm{ATP}}$ (which estimates the rate of ATPe hydrolysis, Figure $7 \mathrm{~B}$ ) would be $3 \times 10^{-2} \mathrm{~min}^{-1}$ (Caco-2) and $8 \times 10^{-5} \mathrm{~min}^{-1}$ (E. coli). Thus, the capacity to hydrolyze ATPe was approximately 300 times higher for Caco-2 cells than for bacteria. This is in agreement with Caco- 2 cells exhibiting activities of ectonucleotidases and ectophosphatases, and their derived exosomes exhibiting strong ectoATPase activity $[65,66]$. Thus, the observed ATPe decay kinetics of Figure 7D was governed by the extracellular ATPase activity of Caco-2 cells, with no contribution from E. coli. 
As complementary proof for the effect of $E$. coli on intestinal cells, we used rat jejunum segments.

Unlike Caco-2 cells, which represent an in vitro model of the enterocytes lining the intestinal cavity, rat intestinal segments conserve the complete intestinal wall structure. [ATPe] significantly increased shortly after E. coli injection into rat jejunum segments (Figure 8A). Similarly, injection of the pathogenic Gram-negative Shigella flexneri in rabbit ileum segments caused luminal ATP release [70]. Interestingly, the observed $\mathrm{ATP}_{\mathrm{L}}$ increase was not only due to intestinal ATP release, but also to the endogenous ATPe of bacteria (Figure 8C).

The above considerations imply that $E$. coli are strong inducers of ATPe kinetics of intestinal cells. On the other hand, E. coli and their OMVs might release low micromolar ATPe under situations compromising their integrity (Figures 4,6). This could activate P2Y2 (EC50 for ATP $\approx 80 \mathrm{nM}$ ) [68], which are functional at the apical domain of Caco-2 cells [71,72]. Activation of $\mathrm{P}_{2} \mathrm{Y}_{2,4,6}$ receptors of intestinal cells and various intestinal cell lines has been shown to regulate transepithelial ionic transport $[73,74]$.

In short, the results of the present study show that E. coli can trigger apical ATP release from an intestinal epithelial cell model and rat intestinal segments, and simultaneously take up and hydrolyze submicromolar ATP. ATPe hydrolysis can be further enhanced by the ectoATPase activity of Caco-2 cells, and potentially by ATPase activity of OMVs. This is metabolically important since E. coli is also permeable to ATPe hydrolysis products such as ADP and AMP [4].

Given that the intestinal mucosa is a purine-limited environment [75], ATPe metabolism by E. coli could be part of a nutritional program whereby successful colonization of the colon by at least five different, nonpathogenic, E. coli strains depend upon competition for nutrients with a dense and diverse microbiota, with up to 1000 different commensal species [76].

Alternatively, ATP release by bacteria may supply energy and hence facilitate the formation and survival of bacterial communities [3].

Future studies would allow elucidating the extent to which bacteria and OMVs can modulate nucleotidedependent cellular and systemic responses of the host, such as inflammation, proliferation, vasodilation, apoptosis, and cell volume.

\section{Abbreviations}

AMP-CPP: $\alpha, \beta$-methyleneadenosine 5'-triphosphate; AphA: acid phosphatase; ATPe: extracellular adenosine triphosphate; ATPL: luminal adenosine triphosphate; IM: inner membrane; OM: outer membrane; OMVs: outer membrane vesicles; MEL: melittin; MST7: mastoparan 7; PhoA: alkaline phosphatase

\section{Author Contribution}

C.L.A., G.C., N.L., I.M.F., L.D.M.F., N.E., S.M.M., V.M., M.A.O., V.H., and P.J.S. conceived and designed the experiments. C.L.A., G.C., N.L., I.M.F., L.D.M.F., N.E., and S.M.M. performed the experiments. C.L.A., G.C., V.M., M.A.O., V.H., and P.J.S. analyzed the data. M.A.O., V.M., V.H., and P.J.S. contributed reagents/materials/ analysis tools. C.L.A. and P.J.S. wrote the paper. V.M., V.N., and M.A.O. gave advice on experimental design and hypothesis. M.A.O., V.M., and V.H. gave critical revision of manuscript.

\section{Funding}

Grant [PIP 11220110100639 and 11220150100459$]$, Consejo Nacional de Investigaciones Científicas y Técnicas, P.J.S. [Grant 20020130100027BA], Universidad de Buenos Aires. PJS. [Grant PICT 2014-0327], Agencia Nacional de Promoción Científica y Técnica, P.J.S. [Grant PDTS/CIN 2014 193], Consejo Nacional de Investigaciones Científicas y Técnicas, P.J.S. ECOS Sud(France)-MINCYT(Argentina) A15S01, P.J.S.-M.A.O. The funders had no role in study design, data collection and analysis, decision to publish, or preparation of the manuscript.

\section{Acknowledgements}

C.L.A., G.C., V.H., V.M., and P.J.S. are career researchers at Consejo Nacional de Investigaciones Científicas y Técnicas (CONICET). M.F.L.D. and N.E. are CONICET postdoctoral fellowship holders. M.A.O. is a professor at Paris Diderot University.

I.M.F. is a PhD student and Monitorat at Universite Paris Diderot Paris 7.

S.M.M. is a researcher at Comisión de Investigaciones Científicas (CIC) of Argentina. The plasmid pGEM3ZF was kindly gifted by Dr J. Santos (IQUIFIB, Univ. Buenos Aires). We are grateful to Mario Ramos for designing the schemes of Figure 9 and Supplementary Figure S2. 
Caco-2 cells were kindly provided by Dra M. Siri, Dr M. Rumbo, and Dr E. Cafferata. We are grateful to S. Verstraeten for constructive comments on an early version of the paper, V. Castilla for providing melittin to perform preliminary experiments, and M.V. Espelt for technical advice regarding cell culture.

This work was supported by: Consejo Nacional de Investigaciones Científicas y Técnicas (Grant PIP 112 20110100639 and 11220150100459); Universidad de Buenos Aires (Grant 20020130100027BA); Agencia Nacional de Promoción Científica y Técnica (Grant PICT 2014-0327); Consejo Nacional de Investigaciones Científicas y Técnicas (Grant PDTS/CIN 2014 193) and ECOS Sud(France)-MINCYT(Argentina).

\section{Competing Interests}

The Authors declare that there are no competing interests associated with the manuscript.

\section{References}

1 Lasko, D.R. and Wang, D.I.C. (1996) On-line monitoring of intracellular ATP concentration in Escherichia coli fermentations. Biotechnol. Bioengineer. 52, 364-372

2 Schneider, D.A. and Gourse, R.L. (2004) Relationship between growth rate and ATP concentration in Escherichia coll: a bioassay for available cellular ATP. J. Biol. Chem. 279, 8262-8268

3 Mempin, R., Tran, H., Chen, C., Gong, H., Kim Ho, K. and Lu, S. (2013) Release of extracellular ATP by bacteria during growth. BMC Microbiol. 13, 301

4 Watanabe, K., Tomioka, S., Tanimura, K., Oku, H. and Isoi, K. (2011) Uptake of AMP, ADP, and ATP in Escherichia coli, W. Biosci. Biotechnol. Biochem. 75, 7-12

5 Kakehi, M., Usuda, Y., Tabira, Y. and Sugimoto, S. (2007) Complete deficiency of 5'-nucleotidase activity in Escherichia coli leads to loss of growth on purine nucleotides but not of their excretion. J. Mol. Microbiol. Biotechnol. 13, 96-104

6 Heller, K.B. and Wilson, T.H. (1981) Selectivity of the Escherichia coli outer membrane porins ompC and ompF. FEBS Lett. 129, 253-255

7 Samartzidou, H. and Delcour, A.H. (1999) Distinct sensitivities of OmpF and PhoE porins to charged modulators. FEBS Lett. 444, 65-70

8 Benz, R., Schmid, A., Nakae, T. and Vos-Scheperkeuter, G.H. (1986) Pore formation by LamB of Escherichia coli in lipid bilayer membranes. J. Bacteriol. 165, 978-986

9 Gee, M.L., Burton, M., Grevis-James, A., Hossain, M.A., McArthur, S., Palombo, E.A. et al. (2013) Imaging the action of antimicrobial peptides on living bacterial cells. Sci. Rep. 3, 1557

10 Mathis, R.R. and Brown, O.R. (1976) ATP concentration in Escherichia coli during oxygen toxicity. Biochim. Biophys. Acta. 440, 723-732

11 Soini, J., Falschlehner, C., Mayer, C., Böhm, D., Weinel, S., Panula, J. et al. (2005) Transient increase of ATP as a response to temperature up-shift in Escherichia coli. Microb. Cell Fact. 4, 9

12 Ivanova, E.P., Alexeeva, Y.V., Pham, D.K., Wright, J.P. and Nicolau, D.V. (2006) ATP level variations in heterotrophic bacteria during attachment on hydrophilic and hydrophobic surfaces. Int. Microbiol. 9, 37-46 PMID:16636988

13 Weiss, B. (2007) Yjjg, a dUMP phosphatase, is critical for thymine utilization by Escherichia coli K-12. J. Bacteriol. 189, 2186-2189

14 Cowman, A. and Beacham, I.R. (1980) Molecular cloning of the gene (ush) from Escherichia coli specifying periplasmic UDP-sugar hydrolase (5'-nucleotidase). Genetics 12, 281-286 PMID:6265322

15 Sträter, N. (2006) Ecto-5'-nucleotidase: structure function relationships. Purinergic Signal. 2, 343-350

16 Thaller, M.C., Schippa, S., Bonci, A., Cresti, S. and Rossolini, G.M. (1997) Identification of the gene (aphA) encoding the class B acid phosphatase/ phosphotransferase of Escherichia coli MG1655 and characterization of its product. FEMS Microbiol. Lett. 146, 191-198

17 Torriani, A. and Rothman, F. (1961) Mutants of Escherichia coli constitutive for alkaline Phosphatase1. J. Bacteriol. 81, 835-836 PMCID:PMC279101

18 Chaidaroglou, A., Brezinski, D.J., Middleton, S.A. and Kantrowitz, E.R. (1988) Function of arginine- 166 in the active site of Escherichia coli alkaline phosphatase. Biochemistry 27, 8338-8343

19 Rao, N.N., Wang, E., Yashphe, J. and Torriani, A. (1986) Nucleotide pool in pho regulon mutants and alkaline phosphatase synthesis in Escherichia coli. J. Bacteriol. 166, 205-211

20 Berrier, C., Coulombe, A., Szabo, I., Zoratti, M. and Ghazi, A. (1992) Gadolinium ion inhibits loss of metabolites induced by osmotic shock and large stretch-activated channels in bacteria. Eur. J. Biochem. 206, 559-565

21 Weigel, N.S., Powers, D.A. and Roseman, S. (1982) Sugar transport by the bacterial phosphotransferase system. J. Biol. Chem. 257, 14499-14509

22 Katsu, T., Kuroko, M., Morikawa, T., Sanchika, K., Fujita, Y., Yamamura, H. et al. (1989) Mechanism of membrane damage induced by the amphipathic peptides gramicidin $S$ and melittin. BBA - Biomembranes $\mathbf{9 8 3}, 135-141$

23 Katsu, T., Kuroko, M., Morikawa, T., Sanchika, K., Yamanaka, H., Shinoda, S. et al. (1990) Interaction of wasp venom mastoparan with biomembranes. Biochim. Biophys. Acta 1027, 185-190 PMID:2204429

24 Dempsey, C.E. (1990) The actions of melittin on membranes. Biochim. Biophys. Acta - Reviews on Biomembranes 1031, 143-161

25 Oh, J.-T., Cajal, Y., Skowronska, E.M., Belkin, S., Chen, J., Van Dyk, T.K. et al. (2000) Cationic peptide antimicrobials induce selective transcription of micF and osmY in Escherichia coli. Biochim. Biophys. Acta - Biomembranes. 1463, 43-54

26 Ulvatne, H., Karoliussen, S., Stiberg, T., Rekdal, Ø. and Svendsen, J.S. (2001) JAC against Escherichia coli. Antimicrob. Agents Chemother. 48, 203-208

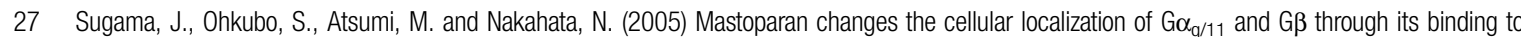
ganglioside in lipid rafts. Mol. Pharmacol. 68, 1466-1474

28 Lin, C.-H., Tzen, J.T.C., Shyu, C., Yang, M.J. and Tu, W.-C. (2011) Peptides structural and biological characterization of mastoparans in the venom of Vespa species in Taiwan. Peptides 32, 2027-2036

29 Walrant, A., Correia, I., Jiao, C.Y., Lequin, O., Bent, E.H., Goasdoué, N. et al. (2011) Different membrane behaviour and cellular uptake of three basic arginine-rich peptides. Biochim. Biophys. Acta - Biomembranes 1808, 382-393 
30 Da Silva, A.V.R., De Souza, B.M., Dos Santos Cabrera, M.P., Dias, N.B., Gomes, P.C., Neto, J.R. et al. (2014) The effects of the C-terminal amidation of mastoparans on their biological actions and interactions with membrane-mimetic systems. Biochim. Biophys. Acta - Biomembranes 1838, 2357-2368

31 Amro, N.A., Kotra, L.P., Wadu-Mesthrige, K., Bulychev, A., Mobashery, S. and Gang-yu, L. (2000) High-resolution atomic force microscopy studies of the Escherichia coli outer membrane: structural basis for permeability. Langmuir 16, 2789-2796

32 Zhang, Y., Phillips, G.J. and Yeung, E.S. (2007) Real-time monitoring of single bacterium lysis and leakage events by chemiluminescence microscopy. Anal. Chem. 79, 5373-5381

33 López-García, B., Gandía, M., Muñoz, A., Carmona, L. and Marcos, J.F. (2010) A genomic approach highlights common and diverse effects and determinants of susceptibility on the yeast Saccharomyces cerevisiae exposed to distinct antimicrobial peptides. BMC Microbiol. 10, 289

34 Laverty, G., Gorman, S.P. and Gilmore, B.F. (2011) The potential of antimicrobial peptides as biocides. Int. J. Mol. Sci. 12, 6566-6596

35 Nakao, S., Komagoe, K., Inoue, T. and Katsu, T. (2011) Comparative study of the membrane-permeabilizing activities of mastoparans and related histamine-releasing agents in bacteria, erythrocytes, and mast cells. Biochim. Biophys. Acta - Biomembranes 1808, 490-497

36 Oren, Z. and Shai, Y. (1997) Selective lysis of bacteria but not mammalian cells by diastereomers of melittin: structure-function study. Biochemistry 36 1826-1835

37 Pandey, B.K., Ahmad, A., Asthana, N., Azmi, S., Srivastava, R.M., Srivastava, S. et al. (2010) Cell-selective lysis by novel analogues of melittin against human red blood cells and Escherichia coli. Biochemistry 49, 7920-7929

38 Leal Denis, M.F., Incicco, J.J., Espelt, M.V., Verstraeten, S.V., Pignataro, O.P., Lazarowski, E.R. et al. (2013) Kinetics of extracellular ATP in mastoparan 7-activated human erythrocytes. Biochim. Biophys. Acta - General Subjects 1830, 4692-4707

39 Leal Denis, M.F., Alvarez, H.A., Lauri, N., Alvarez, C.L., Chara, O. and Schwarzbaum, P.J. (2016) Dynamic regulation of cell volume and extracellular ATP of human erythrocytes. Plos One 11, e0158305

40 Kuroda, A. and Kornberg, A. (1997) Polyphosphate kinase as a nucleoside diphosphate kinase in Escherichia coli and Pseudomonas aeruginosa. Pnas 94, 439-442

41 Legendre, L., Yueh, Y.G., Crain, R., Haddock, N., Heinstein, P.F. and Low, P.S. (1993) Phospholipase C activation during elicitation of the oxidative burst in cultured plant cells. J. Biol. Chem. 268, 24559-24563 PMID:8227014

42 Amano, A., Takeuchi, H. and Furuta, N. (2010) Outer membrane vesicles function as offensive weapons in host-parasite interactions. Microbes Infect. 12, 791-798

43 Kuehn, M.J. and Kesty, N.C. (2005) Bacterial outer membrane vesicles and the host - pathogen interaction. Genes Dev. 19, 2645-2655

44 Kulp, A. and Kuehn, M.J. (2010) Biological functions and biogenesis of secreted bacterial outer membrane vesicles. Ann. Rev. Microbiol. 64, 163-184

45 Kadurugamuwa, J.L. and Beveridge, T.J. (1996) Bacteriolytic effect of membrane vesicles from Pseudomonas aeruginosa on other bacteria including pathogens: conceptually new antibiotics. J. Bacteriol. 178, 2767-2774

46 Li, Z., Clarke, A.J. and Beveridge, T.J. (1996) A major autolysin of Pseudomonas aeruginosa: subcellular distribution, potential role in cell growth and division, and secretion in surface membrane vesicles. J. Bacteriol. 178, 2479-2488

47 Herlax, V., Henning, M.F., Bernasconi, A.M., Goni, F.M. and Bakas, L. (2010) The lytic mechanism of Escherichia coli $\alpha$-hemolysin associated to outer membrane vesicles. Health 02, 484-492

48 Folch, J., Lees, M. and Sloane Stanley, G.H. (1957) A simple method for the isolation and purification of total lipids from animal tissues. J. Biol. Chem. 226, 497-509 PMID:13428781

49 Pafundo, D.E., Chara, O., Faillace, M.P., Krumschnabel, G. and Schwarzbaum, P.J. (2008) Kinetics of ATP release and cell volume regulation of hyposmotically challenged goldfish hepatocytes. Am. J. Physiol. Regul. Integr. Comp. Physiol. 294, R220-R233

50 Montalbetti, N., Leal Denis, M.F., Pignataro, O.P., Kobatake, E., Lazarowski, E.R. and Schwarzbaum, P.J. (2011) Homeostasis of extracellular ATP in human erythrocytes. J. Biol. Chem. 286, 38397-38407

51 Schwarzbaum, P.J., Kaufman, S.B., Rossi, R.C. and Garrahan, P.J. (1995) An unexpected effect of ATP on the ratio between activity and phosphoenzyme level of $\mathrm{Na}+/ \mathrm{K}+-$ ATPase in steady state. Biochim. Biophys. Acta. 1233, 33-40

52 Mackintosh, C. (1993) Protein Phosphorylation: A Practical Approach, (Hardie, D.G., ed.), pp. 197-230, IRL Press, Oxford, UK

53 Torriani, A. (1960) Influence of inorganic phosphate in the formation of phosphatases by Escherichia coli. Biochim. Biophys. Acta. 38, 460-469

54 Koebnik, R., Locher, K.P. and Van Gelder, P. (2000) Structure and function of bacterial outer membrane proteins: barrels in a nutshell. Mol. Microbiol. 37, 239-253

55 Kesty, N.C., Mason, K.M., Reedy, M., Miller, S.E. and Kuehn, M.J. (2004) Enterotoxigenic Escherichia coli vesicles target toxin delivery into mammalian cells. EMBO J. 23, 4538-4549

56 Roier, S., Zingl, F.G., Cakar, F., Durakovic, S., Kohl, P., Eichmann, T.0. et al. (2016) A novel mechanism for the biogenesis of outer membrane vesicles in Gram-negative bacteria. Nat. Commun. 7, 10515

57 Alvarez, C.L., Schachter, J., de Sá Pinheiro, A.A., de Silva, L.S., Verstraeten, S.V., Persechini, P.M. et al. (2014) Regulation of extracellular ATP in human erythrocytes infected with Plasmodium falciparum. PLOS ONE 9, e96216

58 Zimmermann, H. (2016) Extracellular ATP and other nucleotides-ubiquitous triggers of intercellular messenger release. Purinergic Signal. 12, 25-57

59 Holtz, K.M. and Kantrowitz, E.R. (1999) The mechanism of the alkaline phosphatase reaction: insights from NMR, crystallography and site-specific mutagenesis. FEBS Lett. 462, 7-11

60 Xi, C. and Wu, J. (2010) dATP/ATP, a multifunctional nucleotide, stimulates bacterial cell lysis, extracellular DNA release and biofilm development. PLoS ONE 5, e13355

61 Kulkarni, H.M., Swamy, C.V.B. and Jagannadham, M.V. (2014) Molecular characterization and functional analysis of outer membrane vesicles from the antarctic bacterium Pseudomonas syringae suggest a possible response to environmental conditions. J. Proteome Res. 13, 1345-1358

62 Li, Z., Clarke, A.J. and Beveridge, T.J. (1998) Gram-negative bacteria produce membrane vesicles which are capable of killing other bacteria. J. Bacteriol. 180, 5478-5483 PMID:9765585

63 Renelli, M., Matias, V., Lo, R.Y. and Beveridge, T.J. (2004) DNA-containing membrane vesicles of Pseudomonas aeruginosa PA01 and their genetic transformation potential. Microbiology 150, 2161-2169 
64 Ullrich, N., Caplanusi, A., Brône, B., Hermans, D., Larivière, E., Nilius, B. et al. (2006) Stimulation by caveolin-1 of the hypotonicity-induced release of taurine and ATP at basolateral, but not apical, membrane of Caco-2 cells. Am. J. Physiol. Cell Physiol. 290, C1287-C1296

65 Krolczyk, A.J., Bear, C.E., Lai, P.F. H. and Schimmer, B.P. (1995) Effects of mutations in cAMP-dependent protein kinase on chloride efflux in Caco-2 human colonic carcinoma cells. J. Cell. Physiol. 162, 64-73

66 Battistoni, A. (1996) Crystallization and preliminary X-ray analysis of the monomeric Cu,Zn superoxide dismutase from Escherichia coli. Protein Sci. 5 $2125-2127$

67 Lazarowski, E.R., Sesma, J.I., Seminario-Vidal, L. and Kreda, S.M. (2011) Molecular mechanisms of purine and pyrimidine nucleotide release. Adv. Pharmacol. 61, 221-261

68 Lazarowski, E.R., Boucher, R.C. and Harden, T.K. (2003) Mechanisms of release of nucleotides and integration of their action as P2X-and P2Y-receptor activating molecules. Mol. Pharmacol. 64, 785-795

69 Lazarowski, E.R. (2012) Vesicular and conductive mechanisms of nucleotide release. Purinergic Signal 8, 359-373

70 Puhar, A., Tronchère, H., Payrastre, B., Tran Van Nhieu, G. and Sansonetti, P.J. (2013) A shigella effector dampens inflammation by regulating epithelial release of danger signal ATP through production of the lipid mediator Ptdlns5P. Immunity 39, 1121-1131

71 McAlroy, H.L., Ahmed, S., Day, S.M., Baines, D.L., Wong, H.Y., Yip, C.Y. et al. (2000) Multiple P2Y receptor subtypes in the apical membranes of polarized epithelial cells. Br. J. Pharmacol. 131, 1651-1658

72 Buzzi, N., Bilbao, P.S., Boland, R. and de Boland, A.R. (2009) Extracellular ATP activates MAP kinase cascades through a P2Y purinergic receptor in the human intestinal Caco-2 cell line. Biochim. Biophys. Acta 1790, 1651-1659

73 Ghanem, E., Robaye, B., Leal, T., Leipziger, J., Van Driessche, W., Beauwens, R. et al. (2005) The role of epithelial P2Y ${ }_{2}$ and P2Y ${ }_{4}$ receptors in the regulation of intestinal chloride secretion. Br. J. Pharmacol. 146, 364-369

74 Matos, J.E., Sorensen, M.V., Geyti, C.S., Robaye, B., Boeynaems, J.M. and Leipziger, J. (2007) Distal colonic Na+ absorption inhibited by luminal P2Y 2 receptors. Pflugers Arch. 454, 977-987

75 Crane, J.K., Olson, R.A., Jones, H.M. and Duffey, M.E. (2002) Release of ATP during host cell killing by enteropathogenic E. coli and its role as a secretory mediator. Am. J. Phys. Gastrointest. Liver Physiol. 283, G74-G86

76 Conway, T. and Cohen, P.S. (2015) Commensal and pathogenic Escherichia coli metabolism in the Gut. Microbiol. Spectrum 3, 343-362 